\title{
Functional heterogeneity of mesenchymal stem cells from natural niches to culture conditions: implications for further clinical uses
}

\author{
Luis A. Costa ${ }^{1}$ Noemi Eiro ${ }^{1} \cdot$ María Fraile ${ }^{1} \cdot$ Luis O O. Gonzalez $^{1,2} \cdot$ Jorge Saá $^{1} \cdot$ Pablo Garcia-Portabella ${ }^{1} \cdot$ Belén Vega ${ }^{1}$. \\ José Schneider ${ }^{3}$. Francisco J. Vizoso ${ }^{1}$ (i)
}

Received: 28 April 2020 / Revised: 2 July 2020 / Accepted: 13 July 2020 / Published online: 22 July 2020

(c) Springer Nature Switzerland AG 2020

\begin{abstract}
Mesenchymal stem cells (MSC) are present in all organs and tissues. Several studies have shown the therapeutic potential effect of MSC or their derived products. However, the functional heterogeneity of MSC constitutes an important barrier for transferring these capabilities to the clinic. MSC heterogeneity depends on their origin (biological niche) or the conditions of potential donors (age, diseases or unknown factors). It is accepted that many culture conditions of the artificial niche to which they are subjected, such as $\mathrm{O}_{2}$ tension, substrate and extracellular matrix cues, inflammatory stimuli or genetic manipulations can influence their resulting phenotype. Therefore, to attain a more personalized and precise medicine, a correct selection of MSC is mandatory, based on their functional potential, as well as the need to integrate all the existing information to achieve an optimal improvement of MSC features in the artificial niche.
\end{abstract}

Keywords Regenerative medicine $\cdot$ Aging diseases $\cdot$ Diabetes $\cdot$ Lupus $\cdot$ Secretome $\cdot$ Conditioned medium $\cdot$ Extracellular vesicles $\cdot$ Exosomes

\begin{tabular}{|c|c|c|c|c|}
\hline \multicolumn{3}{|c|}{ Abbreviations } & CIN & Cervical intraepithelial neoplasia \\
\hline \multicolumn{2}{|c|}{$2 \mathrm{D}$} & Two-dimensional & $\mathrm{CM}$ & Conditioned medium \\
\hline \multicolumn{2}{|c|}{$3 \mathrm{D}$} & Three-dimensional & CTL & Cytotoxic T lymphocyte \\
\hline \multicolumn{2}{|c|}{ AD } & Adipose-derived & CXCR & $\mathrm{C}-\mathrm{X}-\mathrm{C}$ chemokine receptor \\
\hline \multicolumn{2}{|c|}{ AD-MSC } & Adipose-derived mesenchymal stem cell & DAMPs & Damage-associated molecular patterns \\
\hline \multicolumn{2}{|c|}{ Ad-FKN } & Adenoviral vector fractalkine gene & DNA & Deoxyribonucleic acid \\
\hline \multicolumn{2}{|c|}{$\mathrm{BM}$} & Bone marrow & DPSC & Dental pulp stem cell \\
\hline \multirow{2}{*}{\multicolumn{2}{|c|}{ BM-MSC }} & Bone marrow-derived mesenchymal stem & ECM & Extracellular matrix \\
\hline & & cell & EGF & Epidermal growth factor \\
\hline \multirow{2}{*}{\multicolumn{2}{|c|}{ bBM-MSC }} & Bovine bone marrow-derived mesenchymal & EVs & Extracellular vesicles \\
\hline & & stem cell & EMA & European Medicines Agency \\
\hline \multicolumn{2}{|c|}{ BNDF } & Brain-derived neurotrophic factor & FDA & Food and Drug Administration \\
\hline \multicolumn{2}{|c|}{ CD } & Cluster of differentiation & FGF & Fibroblast growth factor \\
\hline \multirow{2}{*}{\multicolumn{2}{|c|}{ cGMP }} & Current good manufacturing practice & GVHD & Graft-versus-host disease \\
\hline & & & hAFMSC & Human amniotic fluid mesenchymal stem \\
\hline \multicolumn{3}{|c|}{ Luis A. Costa and Noemi Eiro contributed equally to this work. } & HGF & Hepatocyte growth factor \\
\hline \multirow[t]{2}{*}{$\square$} & \multicolumn{2}{|c|}{$\begin{array}{l}\text { Francisco J. Vizoso } \\
\text { investigacion@ @ospitaldejove.com }\end{array}$} & hMESC & $\begin{array}{l}\text { Human endometrium-derived mesenchymal } \\
\text { stem cell }\end{array}$ \\
\hline & \multirow{3}{*}{\multicolumn{2}{|c|}{$\begin{array}{l}\text { Unidad de Investigación, Fundación Hospital de Jove, Avda. } \\
\text { Eduardo Castro 161, } 33920 \text { Gijón, Asturias, Spain }\end{array}$}} & hUCESC & Human uterine cervical stem cells \\
\hline & & & IDO & Indoleamin2,3-dioxygenase \\
\hline & & & IFN $\alpha$ & Interferon alpha \\
\hline & \multirow{2}{*}{\multicolumn{2}{|c|}{$\begin{array}{l}\text { Department of Anatomical Pathology, Fundación Hospital de } \\
\text { Jove, Gijón, Spain }\end{array}$}} & IFN $\beta$ & Interferon beta \\
\hline & & & $\mathrm{IFN} \gamma$ & Interferon gamma \\
\hline & \multicolumn{2}{|c|}{ Department of Obstetrics and Gynecology, University } & IGF & Insulin-like growth factor \\
\hline
\end{tabular}




$\begin{array}{ll}\text { IL } & \text { Interleukin } \\ \text { iNOS } & \text { Inducible nitric oxide synthase } \\ \text { KLF4 } & \text { Kruppel-like Factor 4 } \\ \text { LAP } & \text { Liver-enriched transcriptional activator } \\ & \text { protein } \\ \text { LIF } & \text { Leukemia inhibitory factor } \\ \text { LPS } & \text { Lipopolysaccharide } \\ \text { MAPK } & \text { Mitogen-activated protein kinase } \\ \text { MHC } & \text { Major histocompatibility complex } \\ \text { MMP } & \text { Matrix metalloproteinase } \\ \text { MSC } & \text { Mesenchymal stem cell } \\ \text { NK } & \text { Natural killer cell } \\ \text { NO } & \text { Nitric oxide } \\ \text { PAMPs } & \text { Pathogen-associated molecular patterns } \\ \text { PBMCs } & \text { Peripheral blood mononuclear cells } \\ \text { PDGF } & \text { Platelet-derived growth factor } \\ \text { PDGFR } & \text { Platelet-derived growth factor receptor } \\ \text { PGE2 } & \text { Prostaglandin E2 } \\ \text { PGN } & \text { Peptidoglycan } \\ \text { PIGF } & \text { Placenta growth factor } \\ \text { PDLSC } & \text { Periodontal ligament stem cell } \\ \text { O } & \text { Oxygen } \\ \text { RNA } & \text { Ribonucleic acid } \\ \text { SCAP } & \text { Stem cells from the apical papilla } \\ \text { SHED } & \text { Stem cell from human exfoliated deciduous } \\ & \text { teeth } \\ \text { SWAT } & \text { Subcutaneous white adipose tissue } \\ \text { TGF } \alpha & \text { Transforming growth factor alpha } \\ \text { TGF } \beta & \text { Transforming growth factor beta } \\ \text { TIMP } & \text { Tissular inhibitor of metalloproteases } \\ \text { TLR } & \text { Toll-like receptor } \\ \text { TNF } \alpha & \text { Tumor necrosis factor alpha } \\ \text { TRAIL } & \text { Tumor necrosis-factor-related apoptosis- } \\ & \text { inducing ligand } \\ \text { UC } & \text { Umbilical cord } \\ \text { UC-MSC } & \text { Umbilical cord-derived mesenchymal stem } \\ & \text { cell } \\ \text { VEGF } & \text { Vascular endothelial growth factor } \\ \text { VLC } & \text { Vascular leukocytes } \\ \text { VWAT } & \text { Visceral white adipose tissue } \\ & \end{array}$

\section{Introduction}

Among the various stem cell types, i.e., hematopoietic, embryonic, mesenchymal, and induced pluripotent, mesenchymal stem cells (MSC) are awakening an extraordinary interest.

The number of studies devoted to them has been increasing exponentially during the last decade [1]. MSC are implicated in basic functions, such as cell differentiation and proliferation, angiogenesis/vasculogenesis, regulation of the inflammatory process or control of oxidative stress [2]. Numerous pre-clinical studies, testing MSC or their secretome-derived products in animal models, have shown to have therapeutic effects on key pathological processes that are associated with alterations of the internal homeostasis [3-7]. In addition, they also exert antimicrobial effects, indicating that MSC possess an immune function independent of the host's immune system [8]. Likewise, mostly human clinical trials in phase I and phase II have confirmed a positive safety profile in a variety of indications including immunological, bone, heart, or neurodegenerative disorders [9] and we have even results from phase III clinical trials in the case of graft-versus-host disease (GVHD), Crohn's disease, myocardial infarction and liver cirrhosis [1]. A remarkable fact in this context is that no serious adverse effects have been reported following MSC transplantation, whereas the contrary has been the case after allogeneic hematopoietic stem cell transplantation, i.e., allergic reactions to cyclophosphamide, fever, infection, nausea, vomiting, elevation of liver enzymes, macrophage activation syndrome and GVHD [10].

2018 was a milestone in the field of MSC therapy with the first European Medical Agency (EMA) marketing approval of an MSC product. The TiGenix-sponsored phase III clinical trial NCT01541579, reported statistically significant improvement of intra-lesional administration of allogeneic expanded adipose (AD) MSC (darvadstrocel, formerly Cx601) in the treatment of complex perianal fistulas in Crohn's disease patients [11]. In September 2018, Mesoblast announced the positive results of its phase III trial (NCT02336230) with this treatment with allogeneic bone marrow (BM) MSC (remestemcel-L) in children with steroid-refractory acute GVHD, which resulted in the preparation of a licence application for use to the Food and Drug Administration (FDA) in the United States.

For all these reasons, 2019 could be the start of the therapeutic era of MSC [12], such as for example therapies based on MSC for acute respiratory distress syndrome (ARDS) associated to COVID-19 [13]. Nevertheless, many questions should be assessed with regard to this novel technology, including donor selection, cell harvesting, expansion and storage. The identification of predictive efficacy stratification biomarkers, the appropriate posology and route of administration for each indication still need to be determined. To consider all these technological aspects, we have to assume the concept of MSC heterogeneity.

This review addresses some aspects of MSC heterogeneity, as well in their natural niches as under culture conditions, one key aspect to keep in mind for future clinical applications (Fig. 1). 


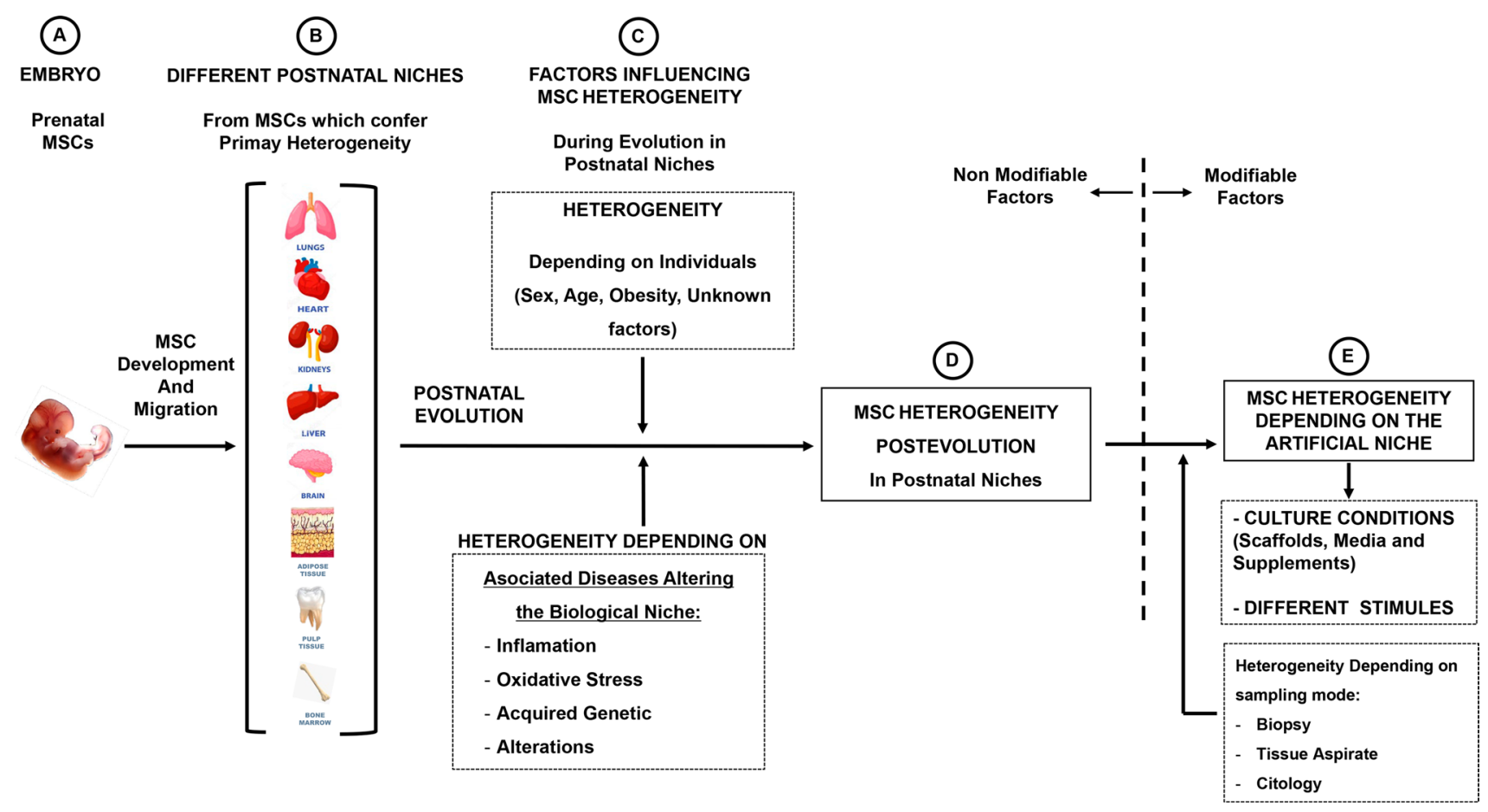

Fig. 1 Schematic representation of MSC heterogeneity in their different niches and factors that could influence their fate

\section{MSC nomenclatures and definition}

MSC were first described in the 1950s by the Russian haematologist Friedenstein, as a rare population in the bone marrow [14]. Although in small amounts, MSC have been isolated from numerous organs and tissues [15]. Adiposederived MSC (AD-MSC) have been the most widely used ones in regenerative medicine, perhaps because of the ease in obtaining them $[16,17]$. Compared with the relatively low yield in BM-MSC (from 0.001 to $0.1 \%$ in the mononuclear fraction) [18], AD tissue can provide up to 500fold more MSC than from an equivalent amount of BM aspirates [19].

Morphologically MSC akin to fibroblasts and are capable of differentiating into mesenchymal lineages [20-22]. To refer to mesenchymal-like cells, various nomenclatures are used, such as "mesenchymal stem cells", "mesenchymal stromal cells", "multipotent stromal cells", "marrow stromal cells" and "medicinal signalling cells [23], but the acronym MSC is now generally used to identify this class of cells. The "International Society for Cellular Therapy" established the minimum criteria required for MSC definition in 2006 as follows: (a) plastic-adherent cells when maintained in standard culture conditions; (b) simultaneous expression of CD105, CD73 and CD90, and lack of expression of CD45, CD34, CD14 or CD19, CD79a or CD11b, and HLA-DR surface molecules and (c) capacity to differentiate into osteoblasts, adipocytes and chondroblasts in vitro [22].

\section{Fetal mesenchymal stem cells}

Platelet-derived growth factor receptor alpha (PDGFRA) is a main marker of MSC in bone marrow [24, 25]. The expression of PDGFRA is critically important for fetal development, and PDGFRA knockout led to embryonic lethality in mouse [26]. Therefore, there is a large number of PDGFRA positive circulating cells in the embryo that decrease immediately after birth. Circulating MSC have rarely been found in the adult circulatory system [27, 28]. However, MSC are present in umbilical cord blood, indicating that circulating MSC/stromal cells in the fetus originate from fetal blood cells [29-31], which exhibit high differentiation potential in mesenchymal lineages (adipocytes, osteocytes, and chondrocytes) [32]. The importance of the original niche on the potentiality of MSC is reflected by the fact that adipose stem cells of embryonic origin show great multi-lineage potential [33]. However, ethical aspects derived from obtaining them do not allow to exploit their potential.

All these data suggest the existence of a migration, dissemination and functional specification of MSC to different niches during fetal development, which seems to represent the start of progressive MSC heterogeneity along the postnatal lifetime (Fig. 1). 


\section{Heterogeneity among MSC from different postnatal niches}

Although investigations into the lineage of these cells strongly suggest that progenitor cells of cultured MSC are of perivascular origin [34, 35], it has been also reported that MSC obtained from various sources differ in their biological features [36, 37]. This suggests that MSC heterogeneity mirrors the diversity of environments present in the natural stem cell niches, which are a consequence of the broad cellular communities that have variable chemical and mechanical conditions. In addition, there is evidence that cultured cells retain biological behaviors related to their previous environments [38] (Fig. 1).

The heterogeneity of MSC is reflected through their different modes of action, such as proliferation capacity, transdifferentiation, immunophenotype or by both paracrine and microvesicle mechanisms via secretome-derived products. Differences according to each one of these mechanisms have been report among MSC from different origins.

\section{Proliferation and differentiation}

There are many examples of differences in proliferation and differentiation among MSC according to their origin. ADMSC exhibit greater proliferative capacity than BM-MSC, but are similar in colony-forming efficiency [39]. Cell proliferation is higher for umbilical cord (UC) MSC compared with BMMSC or AD-MSC [40, 41], or for human uterine cervical stem cells (hUCESC) compared with AD-MSC [42].

With regard to differentiation, greater tendency of BMMSC and AD-MSC to differentiate toward osteoblasts have been observed, whereas there is a lack of differentiation of UC-MSC toward adipocytes [43, 44]. AD-MSC possess also a higher potential for angiogenesis and vasculogenesis [45], as well as a more powerful immunomodulatory potential than BM-MSC [39]. Instead, UC-MSC have the highest potential for chondrogenic differentiation, with a resulting potential for use in tissue engineering [46]. UC-MSC have a higher percentage of neuron-specific enolase-positive cells than BM-MSC after neuronal induction [41]. Placental-MSC have superior migratory capacity but less adipogenic potential [47-49]. MSC from dental origin such as dental pulp (DPSC), deciduous exfoliated teeth (SHED), apical papilla (SCAP) or periodontal ligament (PDLSC) can express several cell markers and differentiate into functionally active neurons, osteoblasts, chondrocytes or vascular cells [50].

\section{Paracrine mechanisms}

MSC secrete a wide range of paracrine factors collectively named as secretome, responsible for up to $80 \%$ of their therapeutic effect. This biological pool includes different bioactive factors such as soluble molecules (cytokines, chemokines and growth factors), but also membranebound vesicles that contain biomolecules. These extracellular vesicles (EVs) may be classified as: (1) exosomes (40-150 $\mathrm{nm}$ in diameter), originating in the endocytic pathway, (2) microparticles (50-1000 $\mathrm{nm}$ in diameter), formed by the outward blebbing of the plasma membrane and subsequent release after the proteolytic cleavage of the cytoskeleton, and (3) apoptotic bodies (500-2000 nm in diameter), which are released during the process of programmed cell death. EVs are phospholipid membranebound particles secreted from cells that contain biomolecules including growth factors, cytokines, lipids, DNA and various forms of RNAs. EVs represent an intercellular communication pathway which plays major roles in mammalian cells in mechanisms such as the exchange of genetic material and the transfer of biologically active molecules as well as in the defense against viral attacks [51]. EVs interact with recipient cells by way of mechanisms which resemble those involved in viral entry. These include binding to surface receptors in order to trigger signal cascades, internalization of surface-bound EVs, and fusion with the cell to deliver material directly to the cytoplasmic membrane and cytosol [52].

Due to all these bioactive factors, MSC have several biological effects, such as regenerative, proliferative, anti-apoptotic, anti-inflammatory, anti-oxidative stress, pro-angiogenic anti-fibrotic, anti-tumor or anti-microbial activities [15, 50, 53-60].

In particular, MSC-derived exosomes, which are complex vesicles containing a large number of proteins and RNA molecules, have been shown to have beneficial therapeutic effects in various models, including those for cutaneous wound healing, diabetic wound healing, atopic dermatitis, corneal epithelial wound healing, traumatic and degenerative ocular disease, autistic-like behaviors, liver fibrosis, hepatic injury, endotoxin-induced acute lung injury, bronchopulmonary dysplasia, E. coli-pneumonia, unspecific lung injury, silica-induced lung fibrosis, osteonecrosis, myocardial infarction, periodontitis or muscle injury [15].

Heterogeneity of secretomes from MSC isolated from different tissues has also been shown. Thus, for example, it has been shown that AD-MSC secrete higher amounts of pro-angiogenic molecules, such as extracellular matrix components and metalloproteinases (MMPs) [40] or vascular endothelial growth factor (VEGF) [61], compared with other MSC such as BM-MSC. This suggests that AD-MSC may be preferred over other MSC populations for augmenting therapeutic approaches dependent upon angiogenesis. Instead, UC-MSC secrete the highest amount of immunomodulatory factors, such as IL-6, -7 and -10 as well as PDGF-AA and TGF- $\alpha[40]$. 


\section{Antitumor effects}

One of the most heterogeneous effects from MSC according to their origin are those on tumors $[62,63]$. Thus, the effects of MSC on tumors are still controversial [64-66]. While it has been shown that MSC are capable of enhancing progression and metastasis of some types of tumor, such as breast cancer and colon cancer [67-71], other studies show that MSC have tumoricidal effects on liver, lung cancer cell lines, and pancreatic tumors in vitro and in vivo [72-75]. Thus, for example, there are many data in the literature suggesting that the effect of MSC on tumors depends on the origin of MSC and the type of tumor. However, we cannot exclude other influences such as growth media, cancer models, host animal model and laboratory bias.

It has been reported that human BM-MSC promoted tumor growth of pancreatic cancer cells [76], osteosarcoma and gastric cancer cell lines [77], and human ADMSC-induced metastasis of breast cancer cells [78]. Several mechanisms have been proposed for these actions, such as MSC recruitment into tumor sites, promoting tumor growth and angiogenesis through the secretion of cytokines [79-81], or protecting cancer cells from immune clearance through modulating regulatory $\mathrm{T}$ cells and inhibiting natural killer (NK) cells and cytotoxic T lymphocyte (CTL) functions [82].

However, it has been shown that the secretome of BMMSC is able to reduce the proliferation, viability and migration of certain types of cancer cells, such as non-small-cell lung carcinoma [83]. It has ben also reported that EVs obtained from BM-MSC inhibit proliferation and promote apoptosis in liver carcinoma, Kaposi's sarcoma, and ovarian tumor cell lines [84]. The same effect was reported for EVs from AD-MSC, that inhibit prostate cancer [84], ovarian cancer cells [85], or glioblastoma [86].

On the other hand, it has been shown that certain MSC, such as those derived from reproductive tissues, have antitumor effects. UC-MSC have a high tendency to move towards the tumor and to inhibit the growth of solid tumors such as breast [87-89] or HeLa cells [90]. The unique features of these cells lead to the hypothesis that UC-MSC act as a natural defense against the migration of cancer cells from mother to fetus, and thus explains why tumors are very rare in the fetus [91]. Endometrial MSC show anti-cancer effects on human epithelial ovarian cancer cells in vitro and in vivo through paracrine factors [92]. Human amniotic fluid MSC (hAFMSC), which can be obtained by amniocentesis in the second trimester or at the end of pregnancy [93], have natural tumor tropism towards ovarian cancer cells, and by releasing soluble factors have an efficient anticancer effect on them [94]. More recently, human uterine cervical stem cells (hUCESC) or their secretome have shown a potent antitumor effect on HeLa cells, highly proliferating breast cancer cells and cancer-associated fibroblasts [42].

It has been shown that MSC may secrete high amounts of cytokines which induce the inhibition of tumor growth, such as IFN $\alpha$ [95], IFN $\beta$ [96], IFN- $\gamma$, DKK-1/3 [97], IL12 [98], TRAIL (Tumor Necrosis- Factor-Related ApoptosisInducing Ligand [99], tumor necrosis factor superfamily member 14 (TNFSF14) also known as LIGHT, Fms-related tyrosine kinase 3 (FLT-3) ligand, C-X-C motif chemokine 10 (CXCL10) and liver-enriched transcriptional activator protein (LAP) [42]. It has been also reported that the antitumor effect of MCS may be partly related to the activity of tissular inhibitors of the matrix metalloproteinases TIMP-1 and TIMP-2 present in their secretome [100, 101], the inhibition of MMPs being associated with the inhibition of migration and invasion of cancer cells.

On the other hand, cancer cells have been shown to internalize a greater percentage of exosomes when compared to normal cells $[102,103]$. These EV produced by MSC may be responsible for many of their antitumor effects. Accordingly, it has been reported that EVs from human UC-MSC reverse the development of bladder carcinoma cells, possibly by down-regulating the phosphorylation of Akt protein kinase and up-regulating cleaved caspase-3 [104]. Human AD-MSC suppress the proliferation of ovarian cancer cells through exosomal miRNA in vitro [85] and inhibit glioblastoma brain xenografts [86]. Likewise, intratumoral injection of miR-146b-expressing MSC-derived exosomes resulted in considerable reduction in glioma xenograft development in a rat brain tumor model and decreased the growth, migration, and invasion of tumor cells [105].

\section{Heterogeneity of MSC in the same postnatal niche in the same individual}

The situation of MSC heterogeneity is even more complex if we consider several findings inside the same postnatal niche. There are some individual factors that have been identified as responsible for this heterogeneity, such as sampling location in the same niche or between individuals, among others.

\section{Depending on sampling location}

It has been found that subcutaneous white adipose tissue (SWAT)-derived MSC show greater proliferation, and are also more easily differentiated to adipose or osteogenic lineages than MSC obtained from visceral white adipose tissue (VWAT) [106]. In addition, AD-MSC isolated from subcutaneous regions show more osteogenic potential than those obtained from deep-layer adipose tissue [107]. 


\section{Depending on individuals}

It is known that when comparing theoretically identical MSC populations from different individuals, they may display different secretome properties, depending on factors including age or health status of the individual [108].

\section{Donor age}

It is known that capabilities from MSC, such as their multilineage differentiation, homing, immunomodulatory and wound-healing capacities, role of oxidative stress regulation or intrinsic changes in telomere shortening, gradually disappear [109-112]. In fact, the properties of BM-MSC are strongly associated with the age of the donor. These cells collected from older donors are characterized by an increased percentage of apoptotic cells and slower proliferation rate, associated with an increased population doubling time. It has also been reported that BM-MSC from older donors have weakened ability to differentiate toward osteoblasts [113] and less reparative capacity [114]. In addition, BM- and AD-MSC obtained from aged individuals possess reduced immunomodulatory properties $[115,116]$ and reduced capacity to handle oxidative stress [117], compared to those from younger ones.

Recently, interesting data on MSC from cervical intraepithelial neoplasia (CIN) were reported [118]. CIN is a precancerous lesion of the uterine cervix that can regress or progress to cervical cancer, and where inflammation seems to play a pivotal role in CIN fate. Patients from a younger age group (mean age $28 \pm 2$ ) express a higher level of cytokines related to acute inflammation than older groups of patients (mean age $45 \pm 3$ ). The mechanisms to explain these differences between MSC are not completely known. Nevertheless, analysis of gene expression related to stemness, such as OCT4, SOX2, NANOG, and KLF4, revealed one discrepancy between young and old MSC. MSC from young women express a higher value of KLF4 than those from old patients. It is known that KLF4 directly binds to the promoter of NANOG to help OCT4 and SOX2 in regulating the expression of NANOG [119]. Considering the critical role of KLF4 in stem cell self-renewal as well as pluripotency, the expression of this factor may contribute to explain the functional differences of MSC depending on women's age.

\section{Obesity}

Adipose tissue is considered an important reservoir for stem cells. However, their function and "stemcellness" has been questioned. This may be, in part, because the influence of obesity as a chronic pathological condition, is a risk factor for cardiovascular disease. In fact, several studies identified changes due to obesity in isolated stem cells from adipose tissue niches. Certainly AD-MSC from obese patients show less differentiation potential and less proangiogenic capacities than those from non-obese individuals [120]. In addition, it was reported that the transcriptomic profile of the stem cells reservoir in obese subcutaneous adipose tissue is highly modified, with significant changes in genes regulating stemcellness, lineage commitment and inflammation [121]. However, the mechanisms of how obesity affects MSC functionality remain unclear. Therefore, functional analysis of MSC from this origin should be performed before clinical application.

\section{Depending on diseases}

A large amount of evidence supports the importance of age on the deterioration of stem cells in adulthood. They can become an important player in the onset of various diseases during aging, such as the metabolic syndrome [122], diabetes [123, 124], rheumatoid arthritis [125], systemic lupus erythematosus [126] or ageing syndromes [127, 128]. Thus, these clinical situations, by perpetuation of inflammatory states, constant emission of "alarm signals," proliferation, mobilization, and finally an endless sequestration of MSC into the damaged tissues, could lead to a decrease in the endogenous pools of progenitor cells, especially MSC, which are probably the most important specialized repairing cells $[129,130]$. Nevertheless, there are also evidences indicating acquired MSC dysfunctions in systemic diseases. This concept arose after the observation of patients with autoimmune diseases such as systemic lupus erythematosus, diabetes, or rheumatoid arthritis, who entered disease remission when treated with mesenchymal or hematopoietic stem cells after allogenic transplants, but not after autologous transplants. Today, MSC dysfunctions are found in patients with diseases such as lupus, diabetes, rheumatoid arthritis, Parkinson disease, amyotrophic lateral sclerosis, psoriasis, idiopathic pulmonary fibrosis or myelodysplastic syndromes. In these diseases, dysfunctional MSC from bone marrow, adipose tissue, umbilical cord or dermis were found [2]. These MSC dysfunctions include multiple alterations such as cytoskeleton-related defects, decreased proliferation and capacity for pluripotency, lower expression of trophic factors, increased cell senescence, apoptosis, activation of the p53/p21 and p16INK4a pathways, reactive oxygen radicals, pro-inflammatory cytokines, impaired potential for differentiation and migration, angiogenesis/vasculogenesis, mitochondrial dysfunction or alterations in metalloproteases [2].

\section{Unknown factors}

Even MSC isolated from young and healthy donors exhibit stark differences in their proliferation rate, differentiation 
capacity, and clinical utility. Thus, for example, in marrow aspirates of 17 healthy donors, it was found that MSC populations showed significant differences in growth rates, alkaline phosphatase enzyme activity or bone-specific gene induction [131]. In addition, it was reported different proliferative rates in MSC cultures from multiple bone marrow aspirates isolated from the same donor over different periods, or bilaterally from a donor at a single time point, yield MSC [131].

All these data on MSC heterogeneity should be considered in the development and application of MSC or their secretome-derived products, possibly using specific functional tests to ensure homogeneity of action.

\section{Heterogeneity of MSC depending on sampling mode}

AD-MSC are an example of heterogeneity of MSC depending on a specific sampling mode. In general, comparison of procedures indicates that a higher surface-to-volume ratio is the most efficient method. Thus, a higher yield of viable AD-MSC is obtained through lipoaspiration, in comparison with those obtained through tissue block resection $[132,133]$. In addition, power-assisted liposuction methodologies show higher proliferative potential and resistance to senescence in isolated AD-MSC than laser-assisted liposuction and surgical biopsy [134]. Also, microaspiration of fat with micro-cannulas has been reported to be more efficient than the usual procedures, as expressed in higher yields, greater viability, better adhesion rates, and greater secretion of growth factors, such as insulin-like growth factor (IGF) and platelet-derived growth factor (PDGF) [135].

Interestingly, other MSC types which show differences with regard to mode sampling are UC-MSC. Thus, it was recently reported that MSC isolated from the UC of babies born vaginally had higher proliferative potential than those obtained from the cord of babies born by Caesarean section, although the reasons are not perfectly clear yet and more studies are underway for clarification [87].

\section{Heterogeneity of MSC depending on the artificial niche}

The possible modifications of MSC culture and their effects are summarized in Table 1. When MSC are placed in an artificial niche, there are several factors which influence their heterogeneity, both under basal conditions and after manipulation.

\section{Basal conditions}

Theoretically, just obtained MSC have morphologic homogeneity and uniform expression of certain surface antigens which are conserved on high-density culture for several passages [22, 136]. However, obtained MSC often represent a mixture of phenotypically, functionally and biochemically diverse cells [137, 138]. In parallel, from passage to passage, the clonogenicity of MSC decreases and proliferation slows down $[139,140]$.

Several studies have shown that single-cell-derived colonies of human MSC contain at least three morphologically disparate cell types: (1) extremely small and rapidly selfrenewing cells; (2) elongated spindle-shaped fibroblast-like cells; and (3) large, cuboidal and slowly replicating cells, [141, 142]. In addition, there exists a clear clonal variability in cell differentiation, proteomic, transcriptomic and epigenetic status.

It has been observed that clones show different potential to differentiation (either osteo-chondro, osteo-adipo or osteoprogenitors) [143]. Probably, these variations in clone differentiation reflect biophysical variation among clones. Cellular mechanical properties reflect the underlying structure of the cell, including the cytoskeleton and nucleus. Mechanical differences of similar magnitude have been noted among individual, undifferentiated MSC isolated and passaged together [144]. Several studies suggest that cellular mechanics can be prospectively used to predict differentiation capacity in individual clones to adipogenic, chondrogenic or osteogenic potentials $[145,146]$.

On the other hand, it has been shown that fast- and slowgrowing clonal populations of MSC differ proteomically, with differential expression of proteins including intermediate filaments, calcium-binding proteins and glycolytic proteins [147]. Epigenetic modifications, such as DNA methylation, is associated stem cell differentiation. Investigation of clonal MSC adipogenesis shows that while adipogenesisassociated promoters are hypomethylated in MSC clones, the specific pattern of methylation varies among clonal subpopulations [148].

\section{Manipulation of MSC in the artificial niche}

The dose or frequency of MSC therapy cannot be increased infinitely in terms of cost and safety. Thus, there is a need for novel strategies to enhance the capability of survival, homing to the site of damage and improving their therapeutic potency. There are several conditions which may contribute to evolutionary changes and heterogeneity of MSC at the artificial niche, such as culture conditions $\left(\mathrm{O}_{2}\right.$ tension, substrate and extracellular cues, inflammatory stimuli or type of culture medium), genetic manipulations or exosome modifications (Fig. 2). 
Table 1 Artificial niche factors that influence heterogeneity of MSC

\begin{tabular}{|c|c|c|c|c|}
\hline Culture condition & MSC source & Type of study & Effect on MSC & References \\
\hline \multirow[t]{3}{*}{ Low $\mathrm{O}_{2}$ tension } & hBM-MSC & In vitro & $\begin{array}{l}\text { Better retention of their proliferative capacity } \\
\text { and differentiation potential. Expression of } \\
\text { surface antigen genes Oct } 4 \text {, Sox } 2 \text { and Nanog }\end{array}$ & {$[149,152]$} \\
\hline & hAD-MSC & In vitro & $\begin{array}{l}\text { Increased expression of AD-MSC stemness } \\
\text { markers Oct } 3 / 4 \text { and Nanog, of secreted } \\
\text { angiogenesis growth factors and increased } \\
\text { proliferation rate. Enhancement of the } \\
\text { chondrogenic differentiation ability. Protec- } \\
\text { tion against damaging factors, replicative } \\
\text { senescence and cryopreservation. Increased } \\
\text { immunomodulatory effect by inhibition the } \\
\text { proliferation of mitogen-stimulated CD4 and } \\
\text { CD8 T lymphocytes }\end{array}$ & {$[59,151,153,154,156,157,163]$} \\
\hline & $\begin{array}{l}\text { hBM-MSC } \\
\text { hAD-MSC }\end{array}$ & In vivo* & $\begin{array}{l}\text { Significantly earlier restoration of blood flow. } \\
\text { Healing of ischemic lesions. Enhanced of } \\
\text { paracrine effect of MSC in diabetes, cancer, } \\
\text { liver failure and irradiation-mediated salivary } \\
\text { gland damage }\end{array}$ & {$[90,150,158-162,164-167]$} \\
\hline \multirow[t]{2}{*}{$\begin{array}{l}\text { Three-dimensional } \\
\text { (3D) aggregates } \\
\text { (spheroids) }\end{array}$} & $\begin{array}{l}\text { Neural } \\
\text { Embrionic and } \\
\text { hAD-MSC }\end{array}$ & In vitro & $\begin{array}{l}\text { Changes in cell shape and polarity. Improve- } \\
\text { ment of cell-cell interactions. Enhanced } \\
\text { differentiation capacity into osteocytes, } \\
\text { chondrocytes and non-mesenchymal lineages. } \\
\text { Increased production of angiogenic factors and } \\
\text { anticancer proteins (TRIL, IL-24 and CD82) }\end{array}$ & {$[170,172-174,181-183,256]$} \\
\hline & & $\begin{array}{l}\text { In vitro } \\
\text { In vivo* }\end{array}$ & $\begin{array}{l}\text { Increased migration and homing efficiency of } \\
\text { MSC to the damaged site with an enhanced } \\
\text { engraftment ratio. Improvement of reparative/ } \\
\text { regenerative and anti-inflammatory properties }\end{array}$ & {$[174,176-180]$} \\
\hline Mechanical stimuli & $\begin{array}{l}\text { bBM-MSC } \\
\text { hMSC }\end{array}$ & In vitro & $\begin{array}{l}\text { Varying stiffness and mechanical loading of } \\
\text { MSC result in changes on biochemical signal- } \\
\text { ling, gene expression, cell phenotype and } \\
\text { paracrine stimulation } \\
\text { Soft environments and low contractility favor } \\
\text { adipogenesis. Stiff milieu and high contractil- } \\
\text { ity promote osteogenic potential }\end{array}$ & {$[185,187-190,192]$} \\
\hline Inflammatory stimuli & $\begin{array}{l}\text { hBM-MSC } \\
\text { UC-MSC } \\
\text { hAD-MSC }\end{array}$ & $\begin{array}{l}\text { In vitro } \\
\text { In vivo* }\end{array}$ & $\begin{array}{l}\text { IFN- } \gamma \text { on MSC culture upregulate the synthe- } \\
\text { sis of indoleamine 2,3-dioxygenase (IDO), } \\
\text { cyclooxygenase } 2 \text { (COX-2), transforming } \\
\text { growth factor beta (TGF- } \alpha \text { ), and hepatocyte } \\
\text { growth factor (HGF) } \\
\text { AD-MSC pre-conditioned with IFN- } \gamma \text {, TNF- } \alpha \\
\text { and IL-6, show enhanced immunosuppres- } \\
\text { sive properties, anti-inflammatory effects, } \\
\text { increased proliferation, mobilization and } \\
\text { osteogenic differentiation } \\
\text { TLR2 and TLR4 dose-dependent activation } \\
\text { enhances AD-MSC osteogenic differentiation, } \\
\text { while triggering TLR9 inhibits osteogenesis } \\
\text { and proliferation } \\
\text { AD-MSC with IFN- } \gamma \text { enhances experimental } \\
\text { obliterative bronchiolitis. AD-MSC with } \\
\text { TNF- } \alpha \text { increases the secretion of interleukin- } 6 \\
\text { (IL-6) and IL- } 8 \text {, stimulating angiogenesis } \\
\text { AD-MSC primed with IFN- } \gamma \text {, TNF- } \alpha \text {, and IL-17 } \\
\text { enhances immunosuppressive effects }\end{array}$ & $\begin{array}{l}{[194-197,200-202,204,206,207]} \\
{[198,199,203,205]}\end{array}$ \\
\hline
\end{tabular}

* animal model 


\section{Culture conditions}

$\mathrm{O}_{2}$ tension The cells are generally cultured in vitro under a $\mathrm{O}_{2}$ tension such as the one present in our atmosphere $(\sim 21 \%)$. However, there are models evidencing that MSC in their niches are adapted to lower $\mathrm{O} 2$ tensions (from 1 to $7 \%)[149,150]$. As an example, the adipose niche is known to be hypoxic, usually with around $5 \% \mathrm{O}_{2}$, compared to highly perfused organs [151]. In addition, several studies have shown that MSC cultured under low $\mathrm{O} 2$ conditions retain better their proliferative capacity, surface antigen expression profile, expression of "stemness" genes (Oct4, Sox 2 , and Nanog), and differentiation potential in comparison with those cultured in atmospheric O2 [152-155]. It has been also shown that hypoxic culture conditions could protect AD-MSC against the most common in vitro damaging factors, replicative senescence and cryopreservation [156, 157].

On the other hand, it has also been reported that MSC under low $\mathrm{O}_{2}$ could drive facilitated release of several trophic factors [59], and especially angiogenesis growth factors such as VEGF and HGF, contributing to an improvement of ischemic lesions [150, 158-162]. In addition, it has been shown that MSC cultured under $1 \%$ $\mathrm{O}_{2}$ display an increased immunomodulatory effect by inhibiting efficiently the proliferation of mitogen-stimulated CD4 and CD8 T lymphocytes [163].
In concordance with all these in vitro data, several in vivo studies showed the advantages of hypoxic pre-conditioning in MSC culture in therapeutic terms. In fact, there are studies reporting that the enhanced paracrine effect of MSC after hypoxic treatment would be beneficial to diabetes [164], liver failure $[165,166]$, irradiation-mediated salivary gland damage [167] or anticancer effects [90]. Nevertheless, despite all these potential therapeutic advantages, there are issues which should be resolved. For example, hypoxia culture conditions might include a wide range of $\mathrm{O}_{2}$ tensions from $5 \%$ to $<1 \%$, which may have different biological effects on MSC. Therefore, the optimal $\mathrm{O}_{2}$ concentration for maximizing each therapeutic effect in each MSC type should be determined prior to clinical application.

Substrate and extracellular matrix cues Aspects related with the specific platform on which the cells are grown and different culture conditions are of key importance. Conventional cell culture is generally conducted in a twodimensional (2D) system (tissue culture flasks-T-flasks) in which cells grow as monolayers. However, under these conditions, the large number of T-flasks needed can lead to flask-to-flask variability, it may increase the chances for contamination, and is certainly very labour intensive [168]. In addition, the 2D system is highly deficient in cell-to-cell or extracellular interactions, which lead to a decrease of stemness of adult stem cells and less therapeutic potential [169]. One alternative is to induce MSC

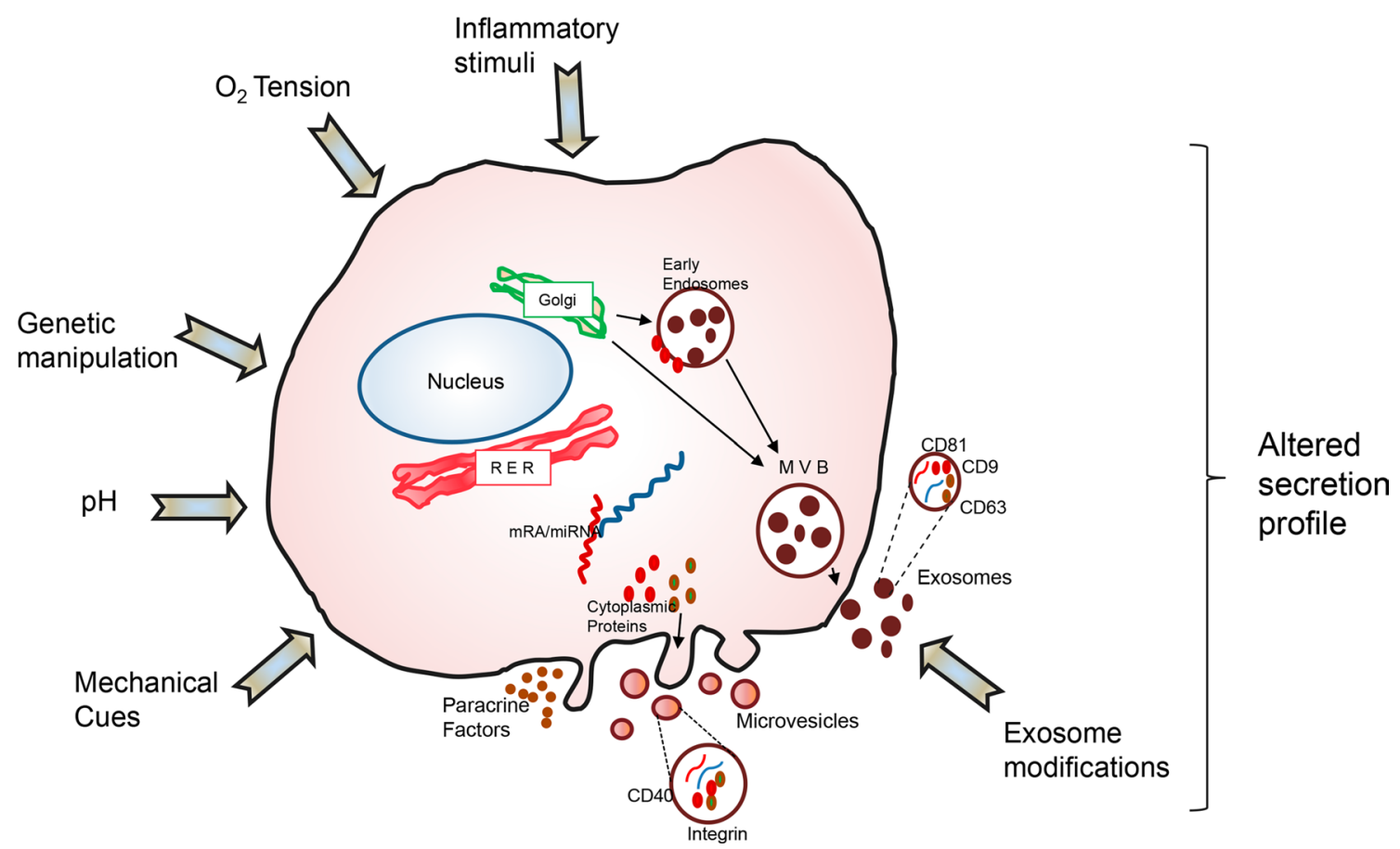

Fig. 2 Factors related to modifiable culture conditions which may influence the quality of MSC to obtain tailor-made secretome-derived products (paracrine factors, microvesicles or exosomes) 
to grow as three-dimensional (3D) aggregates (spheroids). Spheroids are multicellular structures in which adherent cells are forced to aggregate with each other using a suspension culture system [170, 171]. Therefore, cell spheroids change the microenvironment to provide cells with $3 \mathrm{D}$ context and induce changes in cell shape and polarity whilst encouraging cell-cell interactions, which is considered more physiologically adequate. This method was widely applied to culture neural stem cells (neurospheres), embryonic stem cells (embryonic bodies), cancer cells (tumoroids), and other cells to study developmental and physiopathological cell-to-cell dynamics in vitro [170, 172].

It has been reported that MSC cultured as 3D spheroids have properties far superior to those of 2D MSC cultures, such as enhanced differentiation capacity into osteocytes, chondrocytes [173] and non-mesenchymal lineages (ectodermal or endodermal) [174, 175], increase of the migration and homing efficiency of MSC into the damaged site with an enhanced engraftment ratio after in vivo application [174, $176,177]$, increase in reparative/regenerative [177, 178] and anti-inflammatory properties [179, 180], and an increased production of angiogenic factors $[181,182]$ or anticancer proteins (TRIL, IL-24 and CD82) [183].

Despite all these advantages of 3D cultures, there are several technical questions to clarify in order to improve their therapeutic potential, such as optimal size and total cell number of each spheroid, and culture duration [171, 184].

Mechanical cues The elasticity of the microenvironment and exogenous forces are found have been as determinants of stem cell fate [185]. These cues elicit changes in biochemical signalling, gene expression, cell phenotype and function. Cell response is most uniform in extremely soft or stiff environments, which favor adipogenesis and osteogenesis, respectively [186-188]. In addition, subpopulations of undifferentiated MSC encapsulated in hydrogels respond differentially to compression: calcium signalling is upregulated in one subset of cells, while it is downregulated in another [189].

On the other hand, it seems that the MSC secretome may also vary in response to different mechano-transduction events. In a recent study, conditioned medium from mechanically loaded MSC promoted angiogenesis within human dermal microvascular endothelial cells, and that these findings led to significantly increased levels of MMP2, TGF $\beta$, and FGF [190]. Similarly, when MSC are cultured on polyacrylamide hydrogels of increasing stiffness, VEGF and IGF are upregulated, whilst EGF, IL- 6 and IL-8 show biphasic secretory profiles [191]. It has also been shown that after chondrogenic induction through multiaxial mechanical loading, the resulting secretome composition includes soluble factors such as VLC, VEGF, and MMP13 [192].
Inflammatory stimuli Interferon gamma (IFN- $\gamma$ ), a proinflammatory cytokine against viral and bacterial infections, is a known source for MSC priming for functional enhancement [193]. Thus, for example, it has been shown that treatment of MSC with IFN- $\gamma$ upregulates the synthesis of several anti-inflammatory transcription factors, including indoleamine 2,3-dioxygenase (IDO), cyclooxygenase 2 (COX-2), transforming growth factor beta (TGF- $\alpha$ ), and hepatocyte growth factor (HGF) [194-197]. It has been shown that pre-treatment course of AD-MSC with IFN- $\gamma$ improves experimental obliterative bronchiolitis via IDOdependent suppression of $\mathrm{T}$ cell infiltration and induction of regulatory T cells (Tregs) [198], shows pronounced antiproliferative effects on activated peripheral blood mononuclear cells (PBMC) along with a significant upregulation of PD-L1 expression and COX-2-derived PGE2 secretion [199].

Tumor necrosis factor-alpha (TNF- $\alpha$ ) pre-conditioning of MSC exhibit anti-inflammatory effects through upregulation of several immunomodulatory factors [200, 201] can promote bone generation by increasing proliferation, mobilization, and osteogenic differentiation [202], promote endothelial progenitor cell homing and stimulate angiogenesis in a murine ischemic hindlimb model [203].

There are studies conducted to elucidate the optimal combination of cytokines that can maximize the therapeutic effect of MSC. Activation of MSC with TNF- $\alpha$ and IFN- $\gamma$ has been also shown to increase the production of IL-6, HGF, VEGF, and TGF- and to promote bone formation [204]. Murine AD-MSC primed with IFN- $\gamma$, TNF-, and IL-17 attenuates hepatitis through inducible nitric oxide synthase (iNOS)-mediated higher T-cell suppression [205]. Human AD-MSC pre-conditioned with IFN- $\gamma$, TNF- $\alpha$ and IL-6, shows enhanced immunosuppressive properties in vitro [206].

Other inflammation inducers used as to maximize their therapeutic capabilities of MSC are toll-like receptors (TLRs). TLRs represent a subgroup of pattern recognition receptors (PRRs) that contribute to the defense mechanism via the innate immune system in response to pathogen-associated molecular patterns (PAMPs) or damage-associated molecular patterns (DAMPs). The expression of TLR1-6, and 9 have been reported in human MSC [207, 208], and these TLR expression patterns may vary depending on the origin of MSC. It has been shown that activation of TLR2 and TLR4 significantly enhances osteogenic differentiation, whereas triggering TLR9 inhibits osteogenesis and ASC proliferation [207].

Culture medium and new technologies Culture media and new technologies may also influence MSC phenotype. Today different media are used, such as fetal bovine serum, xeno-free or chemically defined media. There have already 
been significant trends towards chemically defined media that remove the batch-to-batch variability associated with foetal bovine serum [209]. Different defined-media formulations are currently commercially available and have been shown to alter secretion of TGF $\beta$ and Ang1 [210], indicating that choice of medium is important.

The 3D self-organized tissue models based on stem cellderived organoid provide biological models to serve as semiphysiological model. Organoids reproduce biological parameters including the cell-cell and cell-matrix interactions, spatial organization and physiological functions [211].

On the other hand, an alternative for expanding large populations of MSC with higher homogeneity and scalable conditions are suspension bioreactors [212]. These techniques are based on the concept of using dynamic suspension cultures of MSC attached to beads to maximise surface area [213].

\section{Genetic manipulation}

AD-MSC transduced with Sox 2 and Oct 4 show remarkable benefits in their proliferation capability. Nevertheless, this manipulation may inhibit differentiation potential and may have possible adverse effects such as tumor formation during clinical applications [214].

There are data suggesting that the incorporation of anti-inflammatory genes such as IL-10 [215], HGF [216], IDO [217], or Foxp3 [218], could improve the therapeutic potential of MSC. Similarly, MSC transfected with Bcl-2 present better apoptotic tolerance, cell survival and more VEGF secretion [219]. While MSC overexpressing bFGF or platelet-derived growth factor-BB (PDGF-BB) lead to highly proliferating MSC and increased osteogenesis [220]. Other MSC were genetically modified to increase their survival, overexpressing factors such as PI3K [221, 222], SDF1 [223], CXCR4 [220, 224], HGF [225] and IGF [226].

In the central nervous system, BDNF is the predominant neurotrophin complemented by the substantial expression of TrkB [227]. Several studies have shown the involvement of BDNF in the pathogenesis of neurodegenerative diseases and psychiatric disorders, like depression and schizophrenia [228]. Additionally, BDNF acts on cholinergic neurons, which are depleted in Alzheimer's disease [229] and on dopaminergic neurons of the substantia nigra, which are lost in Parkinson's disease [230]. However, recombinant BDNF delivery in clinical trials has not been therapeutically successful [231]. Nevertheless, BDNF overexpressing hMSC protect neurons significantly better from degeneration than native MSC. hMSC were lentivirally modified to overexpress BDNF, and which was more neuroprotective [232].

To enhance anticancer effects, in vitro studies have shown that the expression of interferon-beta (IFN- $\beta$ ) in MSC transfected by adenovirus can effectively kill glioma cells [233].
In a model of lung metastasis of prostate cancer, MSC expressing IFN- $\beta$ could prolong the survival period, and its possible mechanism is that IFN- $\beta$ could promote tumor cell apoptosis, inhibit angiogenesis, and increase the activity of natural killer cells [234]. Similarly, adenovirus-transfected MSC expressing interferon- $\gamma$ (IFN- $\gamma$ ) inhibit proliferation and induce apoptosis in leukemia cells in vitro [235]. On the other hand, it has also been shown that MSC engineered to express IL-12 prevent metastasis and increased tumor cell apoptosis in mice bearing preestablished metastases of melanoma, breast, and hepatoma tumors [236, 237].

Despite all these positive data on genetic manipulation of MSC, several limitations remain still limiting their clinical application. The main concern has to do with the fact that the application of replication-defective viral vectors, such as lenti- and adenoviruses, is closely associated with safety issues including potential tumorigenicity, toxicity, and immunogenicity [238]. A summary of verified MSC genetic modifications and their effects is shown in Table 2.

Several studies demonstrated that the Clustered Regularly Interspaced Short Palindromic Repeats (CRISPR)Cas system is highlighted as a simple and effective tool for genetic engineering with applicability to the edition of the mammalian cell genome, and which was tested in clinical trials. It has been recently proposed perspectives on how the CRISPR-Cas system may improve the therapeutic potential of MSCs [239, 240]. In this context, there are today the first evidences of successful and effective MSCs secretome managing via CRISPR/Cas9 genome editing technology. Thereby, using CRISPR-Cas9 knockout and transcriptional activation systems, we were able to create both PAI-1 knockout and PAI-1 over-expressing human endometrium-derived mesenchymal stem cells (hMESCs), respectively [241]. It was also reported the use of engineered BM-MSC overexpressing IL-10 using CRISPR activation to treated myocardial infarction in diabetic mice [242].

\section{Exosome modification}

MSC are the only human cell type known to have a scalable capacity for the mass production of exosomes for drug delivery [243]. They are smaller, less complex, less immunogenic and their production and have easier storage than their parental cells [244]. In addition, other advantages of exosomes include long circulating half-time [245] or better crossing through the blood-brain barrier [246]. Therefore, exosomes can be easily manipulated and can be modified with certain ligands or proteins on their surface to improve their targeting capability.

Exosomes encapsulated with miR-379 have been administered for breast cancer therapy in vivo and migrated to the tumor site showing antitumor effects [247]. It has also been shown that methotrexate-loaded EVs functionalized with a 
Table 2 Influence of genetic manipulation on heterogeneity of MSC

\begin{tabular}{|c|c|c|c|c|}
\hline Genetic modification & MSC source & Type of study & Effect on MSC/therapeutic benefits & References \\
\hline $\begin{array}{l}\text { Sox } 2 \\
\text { Oct } 4 \\
\text { transduction }\end{array}$ & hAD-MSC & In vitro & $\begin{array}{l}\text { Benefits in their proliferation capability, but may inhibit differentiation } \\
\text { potential. Could have adverse effects for clinical applications, such } \\
\text { as tumor formation }\end{array}$ & [214] \\
\hline $\begin{array}{l}\text { IL-10 } \\
\text { HGF } \\
\text { IDO } \\
\text { Foxp3 incorporation }\end{array}$ & hBM-MSC & $\begin{array}{l}\text { In vitro } \\
\text { In vivo* }\end{array}$ & $\begin{array}{l}\text { Attenuates the severity of acute GVHD. Enhanced immunosuppres- } \\
\text { sive properties of MSC. Promotes liver allograft tolerance through } \\
\text { the generation of regulatory T cells }\end{array}$ & {$[215-218]$} \\
\hline $\begin{array}{l}\text { Bcl-2 } \\
\text { engineered }\end{array}$ & hBM-MSC & $\begin{array}{l}\text { In vitro } \\
\text { In vivo* }\end{array}$ & $\begin{array}{l}\text { Better apoptotic tolerance, improved cell survival, VEGF secretion } \\
\text { and reduced heart infarct size }\end{array}$ & [219] \\
\hline $\begin{array}{l}\text { bFGF } \\
\text { PDGF-BB } \\
\text { TGF- } \beta 1 \text { overexpressed }\end{array}$ & hBM-MSC & In vitro & $\begin{array}{l}\text { bFGF or PDGF-B lead to highly proliferating MSC and increase } \\
\text { osteogenesis. Conversely, adipogenesis is affected. } \\
\text { TGF- } \beta 1 \text { blocks both osteogenic and adipogenic differentiation, induc- } \\
\text { ing the formation of stress fibers }\end{array}$ & [220] \\
\hline PI3K-C $2 \alpha$ overexpressed & $\begin{array}{l}\text { BM-MSC } \\
\text { rat }\end{array}$ & $\begin{array}{l}\text { In vitro } \\
\text { In vivo* }\end{array}$ & $\begin{array}{l}\text { The level of apoptotic proteins is downregulated. Increased cell viabil- } \\
\text { ity of MSC and enhanced myocardial regeneration. Reduction of } \\
\text { infarct size and fibrosis area }\end{array}$ & {$[221,222]$} \\
\hline SDF- $1 \alpha$ overexpressed & $\begin{array}{l}\text { BM-MSC } \\
\text { rat }\end{array}$ & $\begin{array}{l}\text { In vitro } \\
\text { In vivo* }\end{array}$ & $\begin{array}{l}\text { MSC differentiation into endothelial cells. Reduction of infarct size } \\
\text { and fibrosis. High vascular density and thicker left ventricular wall. } \\
\text { Improvement of left ventricular performance }\end{array}$ & {$[223]$} \\
\hline CXCR4 overexpressed & hBM-MSC & $\begin{array}{l}\text { In vitro } \\
\text { In vivo* }\end{array}$ & $\begin{array}{l}\text { Enhanced MSC chemokinesis. Improved cell trafficking and tis- } \\
\text { sue repair. Enhancement of relevant trophic signals. No adverse } \\
\text { effects on proliferation and differentiation }\end{array}$ & {$[220,224]$} \\
\hline HGF overexpressed & hBM-MSC & $\begin{array}{l}\text { In vitro } \\
\text { In vivo* }\end{array}$ & $\begin{array}{l}\text { Inhibited collagen deposition and improved cystometric parameters in } \\
\text { bladder outlet obstruction }\end{array}$ & {$[225]$} \\
\hline IGF-I overexpressed & $\begin{array}{l}\text { BM-MSC } \\
\text { mice }\end{array}$ & $\begin{array}{l}\text { In vitro } \\
\text { In vivo* }\end{array}$ & $\begin{array}{l}\text { Paracrine support to EPO-secreting MSC in anemia. Hematocrit } \\
\text { elevation. Improvement of Heart function }\end{array}$ & [226] \\
\hline BDNF overexpressed & hBM-MSC & In vitro & $\begin{array}{l}\text { Lentivirally MSC modification provides significantly neuroprotective } \\
\text { effect from degeneration compared to native hMSC }\end{array}$ & [232] \\
\hline IFN- $\beta$ hMSC engineered & hBM-MSC & $\begin{array}{l}\text { In vitro } \\
\text { In vivo* }\end{array}$ & $\begin{array}{l}\text { In vitro, promotion of tumor cell apoptosis, inhibition of angiogenesis, } \\
\text { and increased NK activity } \\
\text { In vivo, significantly increased survival in a human U87 intracra- } \\
\text { nial glioma xenograft model. Prolonged survival in a prostate cancer } \\
\text { lung metastasis model, compared to controls }\end{array}$ & {$[233,234]$} \\
\hline IFN- $\gamma$ hMSC engineered & hBM-MSC & In vitro & Inhibition of proliferation and induction of apoptosis in leukemia cells & {$[235]$} \\
\hline Ad-FKN engineered & $\begin{array}{l}\text { adenoviral vec- } \\
\text { tor fractalkine } \\
\text { gene }\end{array}$ & $\begin{array}{l}\text { In vitro } \\
\text { In vivo* }\end{array}$ & $\begin{array}{l}\text { Ad-fractalkine mediates antitumor effects by induction of both innate } \\
\text { and adaptive immunity }\end{array}$ & [236] \\
\hline IL-12 expressed & hBM-MSC & $\begin{array}{l}\text { In vitro } \\
\text { In vivo* }\end{array}$ & $\begin{array}{l}\text { Prevention of breast cancer metastasis into the lymph nodes and } \\
\text { internal organs as well as increased tumor cell apoptosis and an } \\
\text { antiangiogenic effect on tumor stroma }\end{array}$ & [237] \\
\hline (CRISPR)/Cas9 & $\begin{array}{l}\text { hMESCs } \\
\text { BM-MSC }\end{array}$ & $\begin{array}{l}\text { In vitro } \\
\text { In vitro } \\
\text { In vivo }\end{array}$ & $\begin{array}{l}\text { Obtain PAI-1 knockout and PAI-1 overexpressing hMESCs, provides } \\
\text { evidence of successful and effective MSCs secretome managing via } \\
\text { CRISPR/Cas9 genome editing technology } \\
\text { Overexpression of IL-10 in BM-MSCs. Transplantation of BM-MSCs } \\
\text { overexpressing IL-10 inhibited inflammatory cell infiltration and } \\
\text { pro-inflammatory cytokines production, improved cardiac functional } \\
\text { recovery, alleviated cardiac injury, decreased apoptosis of cardiac } \\
\text { cells and increased angiogenesis }\end{array}$ & $\begin{array}{l}{[241]} \\
{[242]}\end{array}$ \\
\hline
\end{tabular}

* animal model

synthetic multifunctional peptide facilitated the membrane receptor-mediated internalization procedure both in vitro and in vivo in a glioma model [248].

To enhance vesicle release from cells, other strategies have also been proposed, such as prolonged culture and maintaining cells at low $\mathrm{pH}[249,250]$. Establishment of immortalized MSC is another strategy to scale up EV production [251]. Overexpression of the $c$-myc oncogene, finally, has been reported to increase EV production in MSC [252].

On the other hand, it has been shown that exosomes derived from MSC cultured under hypoxia provide better 
protection in a mouse acute lung injury model than those derived from normoxic MSC [183]. Ischemic preconditioning of MSC has also been to produce EV which reduce cardiac fibrosis and apoptosis compared to control EV [253].

There are recent reports on the use of several human MSC populations treated with sub-lethal concentrations of taxol for $24 \mathrm{~h}$, after which exosomes were isolated and applied to different human cancer populations including A549 lung cancer, SK-OV-3 ovarian cancer, and MDA-hyb1 breast cancer cells. While MSC control exosomes had little or no effect on growth inhibition of the tumor cells, taxol-loaded MSC-derived exosomes were associated with 80-90\% cytotoxicity. Highly metastatic MDA-hyb1 breast tumors were induced in NODscid mice, and systemic intravenous application of MSC-derived taxol exosomes revealed a more than $60 \%$ reduction of subcutaneous primary tumors. Moreover, the amount of distant organ metastases in lung, liver, spleen, and kidney was reduced by 50\% with MSC taxol exosomes, similar to the effects observed with taxol, although the concentration of taxol in the exosomes was about 1000-fold reduced [254].

\section{Conclusions and future perspectives}

MSC are widely distributed throughout the human body and an increasing amount of evidence suggests a significant role for MSC in the regulation of tissue homeostasis. In addition, MSC and products derived from their secretomes, such as $\mathrm{CM}$ or exosomes, need development because of their broad spectrum of therapeutic potentials, such as regenerative, anti-inflammatory, pro-angiogenic, anti-tumor and antimicrobial activities, already demonstrated in several experimental models in vivo. However, one limiting factor in the clinical translation of the therapeutic potential of MSC is related to their heterogeneity.

MSC demonstrate many dimensions of heterogeneity. They differ with regard to their origin among biological niches, donors, as well as among and within clonal populations. Based on this, we may consider that it will probably be necessary in the future to establish stem cell banks based on the heterogeneity of MSC subpopulations. In addition, to screen for cells prior to their use in the clinic, the properties of the cells being used should be better understood.

It is also relevant to consider that once MSC are isolated, their capabilities can vary widely depending on the culture conditions, including physical and chemical ones. This opens new possibilities to modify the potential of MSC through preconditioning of their cultures or genetic manipulation. In particular, advances in bioengineering and our understanding of how the extracellular environment affects MSC paracrine activity will play a pivotal role in the generation of widespread, successful, clinical MSC therapies.
This aspect of the artificial niche represents an opportunity to adapt the possibilities of therapies based on MSC and their derivatives towards personalized medicine tailored to the needs of each patient.

We consider that the most appropriate type of MSC should be chosen for each type of therapeutic application, according to its origin and the result of functional tests after its expansion "in vitro". Likewise, the use of products derived from MSC, such as the secretome, seems to be the most convenient alternative. In this manner, the disadvantages of administering living cells would be avoided, such as thrombosis and possible microembolism [255], and it implies practical and economic advantages [15]. On the other hand, the production of these biological products should be supported by the development of bioreactor technology, which will allow a strict control and optimization of the culture conditions adapted for each type of MSC, as well as the scalable production of large amounts of secretomes for therapeutic use.

Acknowledgements This study was supported by Instituto de Salud Carlos III (PI17/02236) and co-funded by European Union (ERDF/ ESF, "Investing in your future") to F.J.V.

\section{Compliance with ethical standards}

Conflict of interest The authors declare the following competing interests: F.J.V and N.E are co-inventors of a patent ("Human uterine cervical stem cell population and uses thereof") owned by GiStem Research, of which L.A.C, N.E, L.O.G, J.S, P.P J.S. and F.J.V are shareholders. The funding sponsors had no role in the design of this review, in the collection, analyses, or interpretation of data, in the writing of the manuscript, or in the decision to publish the results.

\section{References}

1. Samsonraj RM, Raghunath M, Nurcombe V, Hui JH, van Wijnen AJ, Cool SM (2017) Concise review: multifaceted characterization of human mesenchymal stem cells for use in regenerative medicine. Stem Cells Transl Med 12(6):2173-2185

2. Vizoso FJ, Eiro N, Costa L, Esparza P, Landin M, Diaz-Rodriguez P, Schneider J, Perez-Fernandez R (2019) Mesenchymal stem cells in homeostasis and systemic diseases: hypothesis, evidences, and therapeutic opportunities. Int J Mol Sci. 15(20):3738

3. Lalu MM, Sullivan KJ, Mei SH, Moher D, Straus A, Fergusson DA, Stewart DJ (2016) Evaluating mesenchymal stem cell therapy for sepsis with preclinical meta-analyses prior to initiating a first-in-human trial. Elife 5:e17850

4. McIntyre LA, Moher D, Fergusson DA, Sullivan KJ, Mei SH, Lalu M, Marshall J, McLeod M, Griffin G, Grimshaw J, Turgeon A, Avey MT, Rudnicki MA, Jazi M, Fishman J, Stewart DJ (2016) Efficacy of mesenchymal stromal cell therapy for acute lung injury in preclinical animal models: a systematic review. PLoS One 1(11):e0147170

5. He F (2018) Mesenchymal stem cell therapy for paraquat poisoning: a systematic review and meta-analysis of preclinical studies. Stem cells (Dayton, Ohio) 3(13):e0194748 
6. Riecke J, Johns KM, Cai C, Vahidy FS, Parsha K, Furr-Stimming E, Schiess M, Savitz SI (2015) A meta-analysis of mesenchymal stem cells in animal models of Parkinson's disease. Stem Cells Dev 18(24):2082-2090

7. Galipeau J, Sensebe L (2018) Mesenchymal stromal cells: clinical challenges and therapeutic opportunities. Cell Stem Cell 6(22):824-833

8. Alcayaga-Miranda F, Cuenca J, Khoury M (2017) Antimicrobial activity of mesenchymal stem cells: current status and new perspectives of antimicrobial peptide-based therapies. Front Immunol 8:339

9. Nery AA, Nascimento IC, Glaser T, Bassaneze V, Krieger JE, Ulrich H (2013) Human mesenchymal stem cells: from immunophenotyping by flow cytometry to clinical applications. Cytom Part A (Electron) 1552-4930(83):48-61

10. Zhang LB, He M (2019) Effect of mesenchymal stromal (stem) cell (MSC) transplantation in asthmatic animal models: a systematic review and meta-analysis. Pulm Pharmacol Ther 54:39-52

11. Panes J, Garcia-Olmo D, Van Assche G, Colombel JF, Reinisch W, Baumgart DC, Dignass A, Nachury M, Ferrante M, KazemiShirazi L, Grimaud JC, de la Portilla F, Goldin E, Richard MP, Leselbaum A, Danese S (2016) Expanded allogeneic adiposederived mesenchymal stem cells (Cx601) for complex perianal fistulas in Crohn's disease: a phase 3 randomised, double-blind controlled trial. Lancet (Lond Engl) 10051(388):1281-1290

12. Hoogduijn MJ, Lombardo E (2019) Concise review: mesenchymal stromal cells anno 2019: dawn of the therapeutic era? Stem cells Transl Med. https://doi.org/10.1002/sctm.19-0073

13. Golchin A, Seyedjafari E, Ardeshirylajimi A (2020) Mesenchymal stem cell therapy for COVID-19: present or future. Stem Cell Rev Rep 3(16):427-433

14. Friedenstein AJ, Chailakhjan RK, Lalykina KS (1970) The development of fibroblast colonies in monolayer cultures of guinea-pig bone marrow and spleen cells. Cell Tissue Kinet 4(3):393-403

15. Vizoso FJ, Eiro N, Cid S, Schneider J, Perez-Fernandez R (2017) Mesenchymal stem cell secretome: toward cell-free therapeutic strategies in regenerative medicine. Int J Mol Sci 18:1852

16. Palumbo P, Miconi G, Cinque B, Latorre C, Lombardi F, Zoccali G, Orsini G, Leocata P, Giuliani M, Cifone MG (2015) In vitro evaluation of different methods of handling human liposuction aspirate and their effect on adipocytes and adipose derived stem cells. J Cell Physiol 8(230):974-1981

17. Vallee M, Cote JF, Fradette J (2009) Adipose-tissue engineering: taking advantage of the properties of human adipose-derived stem/stromal cells. Pathol Biol 4(57):309-317

18. Melief SM, Zwaginga JJ, Fibbe WE, Roelofs H (2013) Adipose tissue-derived multipotent stromal cells have a higher immunomodulatory capacity than their bone marrow-derived counterparts. Stem Cells Transl Med 6(2):455-463

19. Hass R, Kasper C, Bohm S, Jacobs R (2011) Different populations and sources of human mesenchymal stem cells (MSC): a comparison of adult and neonatal tissue-derived MSC. Cell Commun Signal CCS 9:12

20. Afanasyev BV, Elstner EE, Zander AR (2009) AJ Friedenstein, founder of the mesenchymal stem cell concept. Cell Ther Transpl $1: 35-38$

21. Uccelli A, Moretta L, Pistoia V (2008) Mesenchymal stem cells in health and disease. Nat Rev Immunol 9(8):726-736

22. Dominici M, Le Blanc K, Mueller I, Slaper-Cortenbach I, Marini F, Krause D, Deans R, Keating A, Prockop D, Horwitz E (2006) Minimal criteria for defining multipotent mesenchymal stromal cells. The International Society for Cellular Therapy position statement. Cytotherapy 4(8):315-317

23. Caplan AI (2017) Mesenchymal stem cells: time to change the name! Stem Cells Transl Med 6(6):1445-1451
24. Takashima Y, Era T, Nakao K, Kondo S, Kasuga M, Smith AG, Nishikawa S (2007) Neuroepithelial cells supply an initial transient wave of MSC differentiation. Cell 7(129):1377-1388

25. Morikawa S, Mabuchi Y, Kubota Y, Nagai Y, Niibe K, Hiratsu E, Suzuki S, Miyauchi-Hara C, Nagoshi N, Sunabori T, Shimmura S, Miyawaki A, Nakagawa T, Suda T, Okano H, Matsuzaki Y (2009) Prospective identification, isolation, and systemic transplantation of multipotent mesenchymal stem cells in murine bone marrow. J Exp Med 11(206):2483-2496

26. Orr-Urtreger A, Bedford MT, Do MS, Eisenbach L, Lonai P (1992) Developmental expression of the alpha receptor for platelet-derived growth factor, which is deleted in the embryonic lethal Patch mutation. Development (Camb Engl) 1(115):289-303

27. He Q, Wan C, Li G (2007) Concise review: multipotent mesenchymal stromal cells in blood. Stem Cells (Dayton, Ohio) 1(25):69-77

28. Zhang Y, Huang B (2012) Peripheral blood stem cells: phenotypic diversity and potential clinical applications. Stem Cell Rev Rep 3(8):917-925

29. Erices A, Conget P, Minguell JJ (2000) Mesenchymal progenitor cells in human umbilical cord blood. Br J Haematol 1(109):235-242

30. Mareschi K, Biasin E, Piacibello W, Aglietta M, Madon E, Fagioli F (2001) Isolation of human mesenchymal stem cells: bone marrow versus umbilical cord blood. Haematologica 0390-6078 (Print) 86:1099-1100

31. Campagnoli C, Roberts IA, Kumar S, Bennett PR, Bellantuono I, Fisk NM (2001) Identification of mesenchymal stem/progenitor cells in human first-trimester fetal blood, liver, and bone marrow. Blood 8(98):2396-2402

32. Guillot PV, Gotherstrom C, Chan J, Kurata H, Fisk NM (2007) Human first-trimester fetal MSC express pluripotency markers and grow faster and have longer telomeres than adult MSC. Stem Cells (Dayton, Ohio) 3(25):646-654

33. Prieto Gonzalez EA (2019) Heterogeneity in adipose stem cells. Adv Exp Med Biol 1123:119-150

34. Shi S, Gronthos S (2003) Perivascular niche of postnatal mesenchymal stem cells in human bone marrow and dental pulp. $\mathbf{J}$ Bone Min Res 4(18):696-704

35. Corselli M, Chen CW, Crisan M, Lazzari L, Peault B (2010) Perivascular ancestors of adult multipotent stem cells. Arterioscler Thromb Vasc Biol 6(30):1104-1109

36. Elahi KC, Klein G, Avci-Adali M, Sievert KD, MacNeil S, Aicher WK (2016) Human mesenchymal stromal cells from different sources diverge in their expression of cell surface proteins and display distinct differentiation patterns. Stem Cells Int. 2016:5646384

37. Chen JY, Mou XZ, Du XC, Xiang C (2015) Comparative analysis of biological characteristics of adult mesenchymal stem cells with different tissue origins. Asian Pac J Trop Med 9(8):739-746

38. Kolf CM, Cho E, Tuan RS (2007) Mesenchymal stromal cells. Biology of adult mesenchymal stem cells: regulation of niche, self-renewal and differentiation. Arthritis Res Therapy 1(9):204

39. Li CY, Wu XY, Tong JB, Yang XX, Zhao JL, Zheng QF, Zhao GB, Ma ZJ (2015) Comparative analysis of human mesenchymal stem cells from bone marrow and adipose tissue under xeno-free conditions for cell therapy. Stem Cell Res Ther 6:55

40. Amable PR, Teixeira MV, Carias RB, Granjeiro JM, Borojevic R (2014) Protein synthesis and secretion in human mesenchymal cells derived from bone marrow, adipose tissue and Wharton's jelly. Stem Cell Res Ther 2(5):53

41. Lu LL, Liu YJ, Yang SG, Zhao QJ, Wang X, Gong W, Han ZB, Xu ZS, Lu YX, Liu D, Chen ZZ, Han ZC (2006) Isolation and characterization of human umbilical cord mesenchymal stem 
cells with hematopoiesis-supportive function and other potentials. Haematologica 8(91):1017-1026

42. Eiro N, Sendon-Lago J, Seoane S, Bermudez MA, Lamelas ML, Garcia-Caballero T, Schneider J, Perez-Fernandez R, Vizoso FJ (2014) Potential therapeutic effect of the secretome from human uterine cervical stem cells against both cancer and stromal cells compared with adipose tissue stem cells. Oncotarget 21(5):10692-10708

43. Heo JS, Choi Y, Kim HS, Kim HO (2016) Comparison of molecular profiles of human mesenchymal stem cells derived from bone marrow, umbilical cord blood, placenta and adipose tissue. Int J Mol Med 1(37):115-125

44. Kern S, Eichler H, Stoeve J, Kluter H, Bieback K (2006) Comparative analysis of mesenchymal stem cells from bone marrow, umbilical cord blood, or adipose tissue. Stem Cells (Dayton Ohio) 5(24):1294-1301

45. Moseley TA, Zhu M, Hedrick MH (2006) Adipose-derived stem and progenitor cells as fillers in plastic and reconstructive surgery. Plastic Reconstr Surg 118(3):121-128

46. Zhang Y, Liu S, Guo W, Wang M, Hao C, Gao S, Zhang X, Li X, Chen M, Jing X, Wang Z, Peng J, Lu S, Guo Q (2018) Human umbilical cord Wharton's jelly mesenchymal stem cells combined with an acellular cartilage extracellular matrix scaffold improve cartilage repair compared with microfracture in a caprine model. Osteoarthr Cartil 7(26):954-965

47. Montesinos JJ, Flores-Figueroa E, Castillo-Medina S, FloresGuzman P, Hernandez-Estevez E, Fajardo-Orduna G, Orozco S, Mayani H (2009) Human mesenchymal stromal cells from adult and neonatal sources: comparative analysis of their morphology, immunophenotype, differentiation patterns and neural protein expression. Cytotherapy 2(11):163-176

48. Li G, Zhang XA, Wang H, Wang X, Meng CL, Chan CY, Yew DT, Tsang KS, Li K, Tsai SN, Ngai SM, Han ZC, Lin MC, He ML, Kung HF (2011) Comparative proteomic analysis of mesenchymal stem cells derived from human bone marrow, umbilical cord and placenta: implication in the migration. Adv Exp Med Biol 720:51-68

49. Li G, Zhang XA, Wang H, Wang X, Meng CL, Chan CY, Yew DT, Tsang KS, Li K, Tsai SN, Ngai SM, Han ZC, Lin MC, He ML, Kung HF (2012) Erratum to: comparative proteomic analysis of mesenchymal stem cells derived from human bone marrow, umbilical cord and placenta: implication in the migration. Adv Exp Med Biol 720:E1

50. Potdar PD, Jethmalani YD (2015) Human dental pulp stem cells: applications in future regenerative medicine. World J Stem Cells 1948-0210 (Print) 26:839-851

51. Rosca AM, Rayia DM, Tutuianu R (2017) Emerging role of stem cells-derived exosomes as valuable tools for cardiovascular therapy. Curr Stem Cell Res Ther 2(12):134-138

52. Pitt JM, Kroemer G, Zitvogel L (2016) Extracellular vesicles: masters of intercellular communication and potential clinical interventions. J Clin Investig 4(126):1139-1143

53. Caplan AI (2007) Adult mesenchymal stem cells for tissue engineering versus regenerative medicine. J Cell Physiol 2(213):341-347

54. Caplan AI, Dennis JE (2006) Mesenchymal stem cells as trophic mediators. J Cell Biochem 5(98):1076-1084

55. Maguire G (2013) Stem cell therapy without the cells. Commun Integr Biol 6(6):e26631

56. Haynesworth SE, Baber MA, Caplan AI (1996) Cytokine expression by human marrow-derived mesenchymal progenitor cells in vitro: effects of dexamethasone and IL-1 alpha. J Cell Physiol 3(166):585-592

57. Patschan D, Plotkin M, Goligorsky MS (2006) Therapeutic use of stem and endothelial progenitor cells in acute renal injury: ca ira. Curr Opin Pharmacol 2(6):176-183
58. Togel F, Hu Z, Weiss K, Isaac J, Lange C, Westenfelder C (2005) Administered mesenchymal stem cells protect against ischemic acute renal failure through differentiation-independent mechanisms. Am J Physiol Renal Physiol 1(289):F31-F42

59. Gnecchi M, He H, Noiseux N, Liang OD, Zhang L, Morello F, Mu H, Melo LG, Pratt RE, Ingwall JS, Dzau VJ (2006) Evidence supporting paracrine hypothesis for Akt-modified mesenchymal stem cell-mediated cardiac protection and functional improvement. FASEB J 6(20):661-669

60. Timmers L, Lim SK, Arslan F, Armstrong JS, Hoefer IE, Doevendans PA, Piek JJ, El Oakley RM, Choo A, Lee CN, Pasterkamp G, de Kleijn DP (2007) Reduction of myocardial infarct size by human mesenchymal stem cell conditioned medium. Stem cell Res 2(1):129-137

61. Hsiao ST, Asgari A, Lokmic Z, Sinclair R, Dusting GJ, Lim SY, Dilley RJ (2012) Comparative analysis of paracrine factor expression in human adult mesenchymal stem cells derived from bone marrow, adipose, and dermal tissue. Stem Cells Dev 12(21):2189-2203

62. Lin W, Huang L, Li Y, Fang B, Li G, Chen L, Xu L (2019) Mesenchymal stem cells and cancer: clinical challenges and opportunities. Biomed Res Int 2019:2820853

63. Rhee KJ, Lee JI, Eom YW (2015) Mesenchymal stem cellmediated effects of tumor support or suppression. Int J Mol Sci 12(16):30015-30033

64. Wong RS (2011) Mesenchymal stem cells: angels or demons? J Biomed Biotechnol 2011:459510

65. Hong IS, Lee HY, Kang KS (2014) Mesenchymal stem cells and cancer: friends or enemies? Mutat Res 768:98-106

66. Norozi F, Ahmadzadeh A, Shahrabi S, Vosoughi T, Saki N (2016) Mesenchymal stem cells as a double-edged sword in suppression or progression of solid tumor cells. Tumour Biol J Int Soc Oncodev Biol Med. 9(37):11679-11689

67. Albarenque SM, Zwacka RM, Mohr A (2011) Both human and mouse mesenchymal stem cells promote breast cancer metastasis. Stem Cell Res 2(7):163-171

68. Shinagawa K, Kitadai Y, Tanaka M, Sumida T, Kodama M, Higashi Y, Tanaka S, Yasui W, Chayama K (2010) Mesenchymal stem cells enhance growth and metastasis of colon cancer. Int J Cancer 10(127):2323-2333

69. Chaturvedi P, Gilkes DM, Wong CC, Luo W, Zhang H, Wei H, Takano N, Schito L, Levchenko A, Semenza GL (2013) Hypoxiainducible factor-dependent breast cancer-mesenchymal stem cell bidirectional signaling promotes metastasis. J Clin Investig 1(123):189-205

70. Vallabhaneni KC, Penfornis P, Dhule S, Guillonneau F, Adams KV, Mo YY, Xu R, Liu Y, Watabe K, Vemuri MC, Pochampally R (2015) Extracellular vesicles from bone marrow mesenchymal stem/stromal cells transport tumor regulatory microRNA, proteins, and metabolites. Oncotarget 7(6):4953-4967

71. Zhong W, Tong Y, Li Y, Yuan J, Hu S, Hu T, Song G (2017) Mesenchymal stem cells in inflammatory microenvironment potently promote metastatic growth of cholangiocarcinoma via activating Akt/NF-kappaB signaling by paracrine CCL5. Oncotarget 43(8):73693-73704

72. Kidd S, Caldwell L, Dietrich M, Samudio I, Spaeth EL, Watson K, Shi Y, Abbruzzese J, Konopleva M, Andreeff M, Marini FC (2010) Mesenchymal stromal cells alone or expressing interferon-beta suppress pancreatic tumors in vivo, an effect countered by anti-inflammatory treatment. Cytotherapy 5(12):615-625

73. Karnoub AE, Dash AB, Vo AP, Sullivan A, Brooks MW, Bell GW, Richardson AL, Polyak K, Tubo R, Weinberg RA (2007) Mesenchymal stem cells within tumour stroma promote breast cancer metastasis. Nature 7162(449):557-563

74. Yulyana Y, Ho IA, Sia KC, Newman JP, Toh XY, Endaya BB, Chan JK, Gnecchi M, Huynh H, Chung AY, Lim KH, Leong HS, 
Iyer NG, Hui KM, Lam PY (2015) Paracrine factors of human fetal MSCs inhibit liver cancer growth through reduced activation of IGF-1R/PI3K/Akt signaling. Mol Ther J Am Soc Gene Ther 4(23): 746-756

75. Liu T, Zhu K, Ke C, Yang S, Yang F, Li Z, Zhang Z (2017) Mesenchymal stem cells inhibited development of lung cancer induced by chemical carcinogens in a rat model. Am J Transl Res 6(9):2891-2900

76. Saito K, Sakaguchi M, Maruyama S, Iioka H, Putranto EW, Sumardika IW, Tomonobu N, Kawasaki T, Homma K, Kondo E (2018) Stromal mesenchymal stem cells facilitate pancreatic cancer progression by regulating specific secretory molecules through mutual cellular interaction. J Cancer 16(9):2916-2929

77. Qi J, Zhou Y, Jiao Z, Wang X, Zhao Y, Li Y, Chen H, Yang L, Zhu H, Li Y (2017) Exosomes derived from human bone marrow mesenchymal stem cells promote tumor growth through hedgehog signaling pathway. Cell Physiol Biochem Int J Exp Cell Physiol Biochem Pharmacol 6(42):2242-2254

78. Gonzalez ME, Martin EE, Anwar T, Arellano-Garcia C, Medhora N, Lama A, Chen YC, Tanager KS, Yoon E, Kidwell KM, Ge C, Franceschi RT, Kleer CG (2017) Mesenchymal stem cell-induced DDR2 mediates stromal-breast cancer interactions and metastasis growth. Cell reports. 5(18):1215-1228

79. Walter M, Liang S, Ghosh S, Hornsby PJ, Li R (2009) Interleukin 6 secreted from adipose stromal cells promotes migration and invasion of breast cancer cells. Oncogene 30(28):2745-2755

80. Tsai KS, Yang SH, Lei YP, Tsai CC, Chen HW, Hsu CY, Chen LL, Wang HW, Miller SA, Chiou SH, Hung MC, Hung SC (2011) Mesenchymal stem cells promote formation of colorectal tumors in mice. Gastroenterology 3(141):1046-1056

81. Zhang T, Lee YW, Rui YF, Cheng TY, Jiang XH, Li G (2013) Bone marrow-derived mesenchymal stem cells promote growth and angiogenesis of breast and prostate tumors. Stem Cell Res Ther 3(4):70

82. Patel SA, Meyer JR, Greco SJ, Corcoran KE, Bryan M, Rameshwar P (2010) Mesenchymal stem cells protect breast cancer cells through regulatory $\mathrm{T}$ cells: role of mesenchymal stem cell-derived TGF-beta. J Immunol (Baltimore Md. 1950) 10(184):5885-5894

83. Attar-Schneider O, Zismanov V, Drucker L, Gottfried M (2016) Secretome of human bone marrow mesenchymal stem cells: an emerging player in lung cancer progression and mechanisms of translation initiation. Tumour Biol J Int Soc Oncodev Biol Med 4(37):4755-4765

84. Takahara K, Ii M, Inamoto T, Nakagawa T, Ibuki N, Yoshikawa Y, Tsujino T, Uchimoto T, Saito K, Takai T, Tanda N, Minami K, Uehara H, Komura K, Hirano H, Nomi H, Kiyama S, Asahi M, Azuma H (2016) microRNA-145 mediates the inhibitory effect of adipose tissue-derived stromal cells on prostate cancer. Stem Cells Dev 17(25):1290-1298

85. Reza A, Choi YJ, Yasuda H, Kim JH (2016) Human adipose mesenchymal stem cell-derived exosomal-miRNAs are critical factors for inducing anti-proliferation signalling to A2780 and SKOV-3 ovarian cancer cells. Sci Rep 6:38498

86. Pacioni S, D'Alessandris QG, Giannetti S, Morgante L, Cocce V, Bonomi A, Buccarelli M, Pascucci L, Alessandri G, Pessina A, Ricci-Vitiani L, Falchetti ML (2017) Human mesenchymal stromal cells inhibit tumor growth in orthotopic glioblastoma xenografts. Physiology (Bethesda, Md.) 1(8):53

87. Mirabdollahi M, Haghjooyjavanmard S, Sadeghi-Aliabadi H (2019) An anticancer effect of umbilical cord-derived mesenchymal stem cell secretome on the breast cancer cell line. Cell Tissue Bank 3(20):423-434

88. Kalamegam G, Sait KHW, Ahmed F, Kadam R, Pushparaj PN, Anfinan N, Rasool M, Jamal MS, Abu-Elmagd M, Al-Qahtani M (2018) Human Wharton's Jelly stem cell (hWJSC) extracts inhibit ovarian cancer cell lines OVCAR3 and SKOV3 in vitro by inducing cell cycle arrest and apoptosis. Front Oncol 8:592

89. Gauthaman K, Fong C-Y, Arularasu S, Subramanian A, Biswas A, Choolani M, Bongso A (2013) Human Wharton's Jelly stem cell conditioned medium and cell-free lysate inhibit human osteosarcoma and mammary carcinoma cell growth in vitro and in xenograft mice. J Cell Biochem 2(114):366-377

90. Han KH, Kim AK, Jeong GJ, Jeon HR, Bhang SH, Kim DI (2019) Enhanced anti-cancer effects of conditioned medium from hypoxic human umbilical cord-derived mesenchymal stem cells. Int J Stem Cells 2(12):291-303

91. Lin HD, Fong CY, Biswas A, Choolani M, Bongso A (2014) Human Wharton's jelly stem cells, its conditioned medium and cell-free lysate inhibit the growth of human lymphoma cells. Stem Cell Rev Rep 4(10):573-586

92. Bu S, Wang Q, Zhang Q, Sun J, He B, Xiang C, Liu Z, Lai D (2016) Human endometrial mesenchymal stem cells exhibit intrinsic anti-tumor properties on human epithelial ovarian cancer cells. eLife 6:37019

93. Babaei G, Naderi R, Alipour S, Gholizadeh-Ghaleh Aziz S (2018) Comparison of traditional prenatal diagnosis procedures and cell-free DNA in maternal plasma as a new molecular approach for prenatal diagnosis. Int J Res Appl Basic Med Sci 2(4):108-118

94. Gholizadeh-Ghaleh Aziz S, Fardyazar Z, Pashaiasl M (2019) The human amniotic fluid mesenchymal stem cells therapy on, SKOV3, ovarian cancer cell line. Mol Genet Genom Med 7(7): 000726

95. Ren C, Kumar S, Chanda D, Chen J, Mountz JD, Ponnazhagan S (2008) Therapeutic potential of mesenchymal stem cells producing interferon-alpha in a mouse melanoma lung metastasis model. Stem Cells (Dayton, Ohio) 9(26):2332-2338

96. Studeny M, Marini FC, Champlin RE, Zompetta C, Fidler IJ, Andreeff M (2002) Bone marrow-derived mesenchymal stem cells as vehicles for interferon-beta delivery into tumors. Cancer Res 13(62):3603-3608

97. Leng L, Wang Y, He N, Wang D, Zhao Q, Feng G, Su W, Xu Y, Han Z, Kong D, Cheng Z, Xiang R, Li Z (2014) Molecular imaging for assessment of mesenchymal stem cells mediated breast cancer therapy. Biomaterials 19(35):5162-5170

98. Chen MY, Lie PC, Li ZL, Wei X (2009) Endothelial differentiation of Wharton's jelly-derived mesenchymal stem cells in comparison with bone marrow-derived mesenchymal stem cells. Exp Hematol 5(37):629-640

99. Grisendi G, Bussolari R, Cafarelli L, Petak I, Rasini V, Veronesi E, De Santis G, Spano C, Tagliazzucchi M, BartiJuhasz H, Scarabelli L, Bambi F, Frassoldati A, Rossi G, Casali C, Morandi U, Horwitz EM, Paolucci P, Conte P, Dominici M (2010) Adipose-derived mesenchymal stem cells as stable source of tumor necrosis factor-related apoptosis-inducing ligand delivery for cancer therapy. Cancer Res 9(70):3718-3729

100. Clarke MR, Imhoff FM, Baird SK (2015) Mesenchymal stem cells inhibit breast cancer cell migration and invasion through secretion of tissue inhibitor of metalloproteinase-1 and -2. Mol Carcinog 10(54):1214-1219

101. Lozito TP, Tuan RS (2011) Mesenchymal stem cells inhibit both endogenous and exogenous MMPs via secreted TIMPs. J Cell Physiol 2(226):385-396

102. Smyth TJ, Redzic JS, Graner MW, Anchordoquy TJ (2014) Examination of the specificity of tumor cell derived exosomes with tumor cells in vitro. Biochem Biophys Acta 11(1838):2954-2965

103. Greco KA, Franzen CA, Foreman KE, Flanigan RC, Kuo PC, Gupta GN (2016) PLK-1 silencing in bladder cancer by siRNA delivered with exosomes. Urology 91:e241-e247 
104. Wu S, Ju GQ, Du T, Zhu YJ, Liu GH (2013) Microvesicles derived from human umbilical cord Wharton's jelly mesenchymal stem cells attenuate bladder tumor cell growth in vitro and in vivo. PLoS One 4(8):e61366

105. Katakowski M, Buller B, Zheng X, Lu Y, Rogers T, Osobamiro O, Shu W, Jiang F, Chopp M (2013) Exosomes from marrow stromal cells expressing miR-146b inhibit glioma growth. Cancer Lett 1(335):201-204

106. Kocan B, Maziarz A, Tabarkiewicz J, Ochiya T, Banaś-Ząbczyk A (2017) Trophic activity and phenotype of adipose tissuederived mesenchymal stem cells as a background of their regenerative potential. Stem Cells Int 2017:1653254

107. Di Taranto G, Cicione C, Visconti G, Isgro MA, Barba M, Di Stasio E, Stigliano E, Bernardini C, Michetti F, Salgarello M, Lattanzi W (2015) Qualitative and quantitative differences of adipose-derived stromal cells from superficial and deep subcutaneous lipoaspirates: a matter of fat. Cytotherapy 8(17):1076-1089

108. Mendicino M, Bailey AM, Wonnacott K, Puri RK, Bauer SR (2014) MSC-based product characterization for clinical trials: an FDA perspective. Cell Stem Cell 2(14):141-145

109. Jones DL, Rando TA (2011) Emerging models and paradigms for stem cell ageing. Nat Cell Biol 5(13):506-512

110. Yu KR, Kang KS (2013) Aging-related genes in mesenchymal stem cells: a mini-review. Gerontology 6(59):557-563

111. Raggi C, Berardi AC (2012) Mesenchymal stem cells, aging and regenerative medicine. Muscles Ligaments Tendons $\mathbf{J}$ 3(2):239-242

112. Li Y, Wu Q, Wang Y, Li L, Bu H, Bao J (2017) Senescence of mesenchymal stem cells (review). Int J Mol Med 1791-244X (Electron) 39:775-782

113. Zhou S, Greenberger JS, Epperly MW, Goff JP, Adler C, Leboff MS, Glowacki J (2008) Age-related intrinsic changes in human bone-marrow-derived mesenchymal stem cells and their differentiation to osteoblasts. Aging Cell 3(7):335-343

114. Alvarez D, Levine M, Rojas M (2015) Regenerative medicine in the treatment of idiopathic pulmonary fibrosis: current position. Stem Cells Cloning Adv Appl 8:61-65

115. Wu LW, Wang YL, Christensen JM, Khalifian S, Schneeberger S, Raimondi G, Cooney DS, Lee WP, Brandacher G (2014) Donor age negatively affects the immunoregulatory properties of both adipose and bone marrow derived mesenchymal stem cells. Transpl Immunol 4(30):122-127

116. Kizilay Mancini O, Shum-Tim D, Stochaj U, Correa JA, Colmegna I (2015) Age, atherosclerosis and type 2 diabetes reduce human mesenchymal stromal cell-mediated T-cell suppression. Stem Cell Res Ther. 6:140

117. De Barros S, Dehez S, Arnaud E, Barreau C, Cazavet A, Perez G, Galinier A, Casteilla L, Planat-Benard V (2013) Aging-related decrease of human ASC angiogenic potential is reversed by hypoxia preconditioning through ROS production. Mol Ther J Am Soc Gene Ther 2(21):399-408

118. Orciani M, Caffarini M, Lazzarini R, Delli Carpini G, Tsiroglou D, Di Primio R, Ciavattini A (2018) Mesenchymal stem cells from cervix and age: new insights into CIN regression rate. Oxid Med Cell Longev 2018:1545784

119. Zhang P, Andrianakos R, Yang Y, Liu C, Lu W (2010) Kruppel-like factor 4 (Klf4) prevents embryonic stem (ES) cell differentiation by regulating Nanog gene expression. J Biol Chem 12(285):9180-9189

120. Onate B, Vilahur G, Ferrer-Lorente R, Ybarra J, Diez-Caballero A, Ballesta-Lopez C, Moscatiello F, Herrero J, Badimon L (2012) The subcutaneous adipose tissue reservoir of functionally active stem cells is reduced in obese patients. FASEB J 10(26):4327-4336

121. Onate B, Vilahur G, Camino-Lopez S, Diez-Caballero A, Ballesta-Lopez C, Ybarra J, Moscatiello F, Herrero J, Badimon L
(2013) Stem cells isolated from adipose tissue of obese patients show changes in their transcriptomic profile that indicate loss in stemcellness and increased commitment to an adipocyte-like phenotype. BMC Genom 14:625

122. Mansilla E, Diaz Aquino V, Zambon D, Marin GH, Martire K, Roque G, Ichim T, Riordan NH, Patel A, Sturla F, Larsen G, Spretz R, Nunez L, Soratti C, Ibar R, van Leeuwen M, Tau JM, Drago H, Maceira A (2011) Could metabolic syndrome, lipodystrophy, and aging be mesenchymal stem cell exhaustion syndromes? Stem Cells Int 2011:943216

123. Leslie WD, Rubin MR, Schwartz AV, Kanis JA (2012) Type 2 diabetes and bone. J Bone Miner Res 11(27):2231-2237

124. Vasam G, Joshi S, Thatcher SE, Bartelmez SH, Cassis LA, Jarajapu YP (2017) Reversal of bone marrow mobilopathy and enhanced vascular repair by angiotensin-(1-7) in diabetes. Diabetes 2(66):505-518

125. Kastrinaki MC, Sidiropoulos P, Roche S, Ringe J, Lehmann S, Kritikos H, Vlahava VM, Delorme B, Eliopoulos GD, Jorgensen C, Charbord P, Haupl T, Boumpas DT, Papadaki HA (2008) Functional, molecular and proteomic characterisation of bone marrow mesenchymal stem cells in rheumatoid arthritis. Ann Rheum Dis 6(67):741-749

126. Gao L, Bird AK, Meednu N, Dauenhauer K, Liesveld J, Anolik J, Looney RJ (2017) Bone marrow-derived mesenchymal stem cells from patients with systemic lupus erythematosus have a senescence-associated secretory phenotype mediated by a mitochondrial antiviral signaling protein-interferon-beta feedback loop. Arthritis Rheumatol 8(69):1623-1635

127. Zhang W, Li J, Suzuki K, Qu J, Wang P, Zhou J, Liu X, Ren R, Xu X, Ocampo A, Yuan T, Yang J, Li Y, Shi L, Guan D, Pan H, Duan S, Ding Z, Li M, Yi F, Bai R, Wang Y, Chen C, Yang F, Li X, Wang Z, Aizawa E, Goebl A, Soligalla RD, Reddy P, Esteban CR, Tang F, Liu GH, Belmonte JC (2015) Aging stem cells A Werner syndrome stem cell model unveils heterochromatin alterations as a driver of human aging. Science (New York, N.Y.) 6239(348):1160-1163

128. Liu GH, Barkho BZ, Ruiz S, Diep D, Qu J, Yang SL, Panopoulos AD, Suzuki K, Kurian L, Walsh C, Thompson J, Boue S, Fung HL, Sancho-Martinez I, Zhang K, Yates J, Izpisua Belmonte JC (2011) Recapitulation of premature ageing with iPSCs from Hutchinson-Gilford progeria syndrome. Nature 7342(472):221-225

129. Shi Y, Hu G, Su J, Li W, Chen Q, Shou P, Xu C, Chen X, Huang Y, Zhu Z, Huang X, Han X, Xie N, Ren G (2010) Mesenchymal stem cells: a new strategy for immunosuppression and tissue repair. Cell Res 5(20):510-518

130. Qian SW, Li X, Zhang YY, Huang HY, Liu Y, Sun X, Tang QQ (2010) Characterization of adipocyte differentiation from human mesenchymal stem cells in bone marrow. BMC Dev Biol 10:47

131. Phinney DG, Kopen G, Righter W, Webster S, Tremain N, Prockop DJ (1999) Donor variation in the growth properties and osteogenic potential of human marrow stromal cells. J Cell Biochem 3(75):424-436

132. Pittenger MF, Mackay AM, Beck SC, Jaiswal RK, Douglas R, Mosca JD, Moorman MA, Simonetti DW, Craig S, Marshak DR (1999) Multilineage potential of adult human mesenchymal stem cells. Science (New York, NY) 5411(284):143-147

133. Schwab KE, Gargett CE (2007) Co-expression of two perivascular cell markers isolates mesenchymal stem-like cells from human endometrium. Hum Reprod (Oxf Engl) 11(22):2903-2911

134. Bajek A, Gurtowska N, Olkowska J, Maj M, Kazmierski L, Bodnar M, Marszalek A, Debski R, Drewa T (2017) Does the harvesting technique affect the properties of adipose-derived stem cells? - the comparative biological characterization. J Cell Biochem 5(118):1097-1107 
135. Sorrentino A, Ferracin M, Castelli G, Biffoni M, Tomaselli G, Baiocchi M, Fatica A, Negrini M, Peschle C, Valtieri M (2008) Isolation and characterization of CD146+ multipotent mesenchymal stromal cells. Exp Hematol 8(36):1035-1046

136. Arufe MC, De la Fuente A, Fuentes I, de Toro FJ, Blanco FJ (2010) Chondrogenic potential of subpopulations of cells expressing mesenchymal stem cell markers derived from human synovial membranes. J Cell Biochem 4(111):834-845

137. Phinney DG (2012) Functional heterogeneity of mesenchymal stem cells: implications for cell therapy. J Cell Biochem 9(113):2806-2812

138. Tormin A, Brune JC, Olsson E, Valcich J, Neuman U, Olofsson T, Jacobsen SE, Scheding S (2009) Characterization of bone marrow-derived mesenchymal stromal cells (MSC) based on gene expression profiling of functionally defined MSC subsets. Cytotherapy 2(11):114-128

139. Schellenberg A, Lin Q, Schuler H, Koch CM, Joussen S, Denecke B, Walenda G, Pallua N, Suschek CV, Zenke M, Wagner W (2011) Replicative senescence of mesenchymal stem cells causes DNA-methylation changes which correlate with repressive histone marks. Aging 9(3):873-888

140. Digirolamo CM, Stokes D, Colter D, Phinney DG, Class R, Prockop DJ (1999) Propagation and senescence of human marrow stromal cells in culture: a simple colony-forming assay identifies samples with the greatest potential to propagate and differentiate. Br J Haematol 2(107):275-281

141. Colter DC, Sekiya I, Prockop DJ (2001) Identification of a subpopulation of rapidly self-renewing and multipotential adult stem cells in colonies of human marrow stromal cells. Proc Natl Acad Sci USA 14(98):7841-7845

142. Prockop DJ, Sekiya I, Colter DC (2001) Isolation and characterization of rapidly self-renewing stem cells from cultures of human marrow stromal cells. Cytotherapy 5(3):393-396

143. Russell KC, Phinney DG, Lacey MR, Barrilleaux BL, Meyertholen KE, O' Connor KC (2010) In vitro high-capacity assay to quantify the clonal heterogeneity in trilineage potential of mesenchymal stem cells reveals a complex hierarchy of lineage commitment. Stem Cells (Dayton, Ohio) 4(28):788-798

144. Maloney JM, Nikova D, Lautenschlager F, Clarke E, Langer R, Guck J, Van Vliet KJ (2010) Mesenchymal stem cell mechanics from the attached to the suspended state. Biophys $\mathbf{J}$ 8(99):2479-2487

145. Gonzalez-Cruz RD, Fonseca VC, Darling EM (2012) Cellular mechanical properties reflect the differentiation potential of adipose-derived mesenchymal stem cells. Proc Natl Acad Sci USA 24(109):E1523-E1529

146. McLeod CM, Mauck RL (2017) On the origin and impact of mesenchymal stem cell heterogeneity: new insights and emerging tools for single cell analysis. Eur Cells Mater 34:217-231

147. Mareddy S, Broadbent J, Crawford R, Xiao Y (2009) Proteomic profiling of distinct clonal populations of bone marrow mesenchymal stem cells. J Cell Biochem 5(106):776-786

148. Noer A, Sorensen AL, Boquest AC, Collas P (2006) Stable $\mathrm{CpG}$ hypomethylation of adipogenic promoters in freshly isolated, cultured, and differentiated mesenchymal stem cells from adipose tissue. Mol Biol Cell 8(17):3543-3556

149. Holzwarth C, Vaegler M, Gieseke F, Pfister SM, Handgretinger R, Kerst G, Muller I (2010) Low physiologic oxygen tensions reduce proliferation and differentiation of human multipotent mesenchymal stromal cells. BMC Cell Biol 11:11

150. Rosova I, Dao M, Capoccia B, Link D, Nolta JA (2008) Hypoxic preconditioning results in increased motility and improved therapeutic potential of human mesenchymal stem cells. Stem Cells (Dayton, Ohio) 8(26):2173-2182
151. Goossens GH, Blaak EE (2012) Adipose tissue oxygen tension: implications for chronic metabolic and inflammatory diseases. Curr Opin Clin Nutr Metab Care 6(15):539-546

152. Hung SP, Ho JH, Shih YR, Lo T, Lee OK (2012) Hypoxia promotes proliferation and osteogenic differentiation potentials of human mesenchymal stem cells. J Orthop Res 2(30):260-266

153. Choi JR, Pingguan-Murphy B, Wan Abas WA, Noor Azmi MA, Omar SZ, Chua KH, Wan Safwani WK (2014) Impact of low oxygen tension on stemness, proliferation and differentiation potential of human adipose-derived stem cells. Biochem Biophys Res Commun 2(448):218-224

154. Yamamoto Y, Fujita M, Tanaka Y, Kojima I, Kanatani Y, Ishihara M, Tachibana S (2013) Low oxygen tension enhances proliferation and maintains stemness of adipose tissue-derived stromal cells. BioRes Open Access 3(2):199-205

155. Werle SB, Chagastelles P, Pranke P, Casagrande L (2016) The effects of hypoxia on in vitro culture of dental-derived stem cells. Arch Oral Biol (Electron) 1879-1506(68):13-20

156. Pallini R, Choi JR, Yong KW, Wan Safwani WKZ (2017) Effect of hypoxia on human adipose-derived mesenchymal stem cells and its potential clinical applications. Stem Cell Res Ther 14(74):2587-2600

157. Wan Safwani WKZ, Choi JR, Yong KW, Ting I, Mat Adenan NA, Pingguan-Murphy B (2017) Hypoxia enhances the viability, growth and chondrogenic potential of cryopreserved human adipose-derived stem cells. Cryobiology 75:91-99

158. Hu X, Yu SP, Fraser JL, Lu Z, Ogle ME, Wang JA, Wei L (2008) Transplantation of hypoxia-preconditioned mesenchymal stem cells improves infarcted heart function via enhanced survival of implanted cells and angiogenesis. J Thorac Cardiovasc Surg 4(135):799-808

159. Hollenbeck ST, Senghaas A, Komatsu I, Zhang Y, Erdmann D, Klitzman B (2012) Tissue engraftment of hypoxic-preconditioned adipose-derived stem cells improves flap viability. Wound Repair Regen 6(20):872-878

160. Leroux L, Descamps B, Tojais NF, Seguy B, Oses P, Moreau C, Daret D, Ivanovic Z, Boiron JM, Lamaziere JM, Dufourcq P, Couffinhal T, Duplaa C (2010) Hypoxia preconditioned mesenchymal stem cells improve vascular and skeletal muscle fiber regeneration after ischemia through a Wnt4-dependent pathway. Mol Ther J Am Soc Gene Ther 8(18):1545-1552

161. Efimenko A, Starostina E, Kalinina N, Stolzing A (2011) Angiogenic properties of aged adipose derived mesenchymal stem cells after hypoxic conditioning. J Transl Med 9:10

162. Liu L, Gao J, Yuan Y, Chang Q, Liao Y, Lu F (2013) Hypoxia preconditioned human adipose derived mesenchymal stem cells enhance angiogenic potential via secretion of increased VEGF and bFGF. Cell Biol Int 6(37):551-560

163. Roemeling-van Rhijn M, Mensah FK, Korevaar SS, Leijs MJ, van Osch GJ, Ijzermans JN, Betjes MG, Baan CC, Weimar W, Hoogduijn MJ (2013) Effects of hypoxia on the immunomodulatory properties of adipose tissue-derived mesenchymal stem cells. Front Immunol 4:203

164. Schive SW, Mirlashari MR, Hasvold G, Wang M, Josefsen D, Gullestad HP, Korsgren O, Foss A, Kvalheim G, Scholz H (2017) Human adipose-derived mesenchymal stem cells respond to short-term hypoxia by secreting factors beneficial for human islets in vitro and potentiate antidiabetic effect in vivo. Stem Cells Int 3(9):103-116

165. Lee SC, Jeong HJ, Lee SK, Kim SJ (2016) Hypoxic conditioned medium from human adipose-derived stem cells promotes mouse liver regeneration through JAK/STAT3 signaling. Stem Cells Transl Med 6(5):816-825

166. Temnov A, Rogov K, Zhalimov V, Igor P, Pekov S, Bader A, Sklifas A, Giri S (2019) The effect of a mesenchymal stem cell conditioned medium fraction on morphological characteristics 
of hepatocytes in acetaminophen-induced acute liver failure: a preliminary study. Hepat Med 11:89-96

167. Shin HS, Lee S, Kim YM, Lim JY (2018) Hypoxia-activated adipose mesenchymal stem cells prevents irradiation-induced salivary hypofunction by enhanced paracrine effect through fibroblast growth factor. Stem Cells 10 7(36):1020-1032

168. Panchalingam KM, Jung S, Rosenberg L, Behie LA (2015) Bioprocessing strategies for the large-scale production of human mesenchymal stem cells: a review. Stem Cell Res Ther 6:225

169. Amelian A, Wasilewska K, Megias D, Winnicka K (2017) Application of standard cell cultures and 3D in vitro tissue models as an effective tool in drug design and development. Pharmacol Rep PR 5(69):861-870

170. Duval K, Grover H, Han LH, Mou Y, Pegoraro AF, Fredberg J, Chen Z (2017) Modeling physiological events in 2D vs. 3D cell culture. Respir Res 4(32):266-277

171. Edmondson R, Broglie JJ, Adcock AF, Yang L (2014) Threedimensional cell culture systems and their applications in drug discovery and cell-based biosensors. Assay Drug Dev Technol 4(12):207-218

172. Griffith LG, Swartz MA (2006) Capturing complex 3D tissue physiology in vitro. Nat Rev Mol Cell Biol 3(7):211-224

173. Tae JY, Lee SI, Ko Y, Park J-B (2017) The use of adipose-derived stem cells for the fabrication of three-dimensional spheroids for the osteogenic differentiation. Biomed Res (India) 28:7098-7103

174. Cheng NC, Wang S, Young TH (2012) The influence of spheroid formation of human adipose-derived stem cells on chitosan films on stemness and differentiation capabilities. Biomaterials 6(33): $1748-1758$

175. Zhang S, Liu P, Chen L, Wang Y, Wang Z, Zhang B (2015) The effects of spheroid formation of adipose-derived stem cells in a microgravity bioreactor on stemness properties and therapeutic potential. Biomaterials 41:15-25

176. Potapova IA, Brink PR, Cohen IS, Doronin SV (2008) Culturing of human mesenchymal stem cells as three-dimensional aggregates induces functional expression of CXCR4 that regulates adhesion to endothelial cells. J Biol Chem 19(283):13100-13107

177. Cheng NC, Chen SY, Li JR, Young TH (2013) Short-term spheroid formation enhances the regenerative capacity of adiposederived stem cells by promoting stemness, angiogenesis, and chemotaxis. Stem Cells Transl Med 8(2):584-594

178. Park IS, Chung PS, Ahn JC (2015) Enhancement of ischemic wound healing by spheroid grafting of human adipose-derived stem cells treated with low-level light irradiation. PLoS One 6(10):e0122776

179. Bartosh TJ, Ylostalo JH, Mohammadipoor A, Bazhanov N, Coble K, Claypool K, Lee RH, Choi H, Prockop DJ (2010) Aggregation of human mesenchymal stromal cells (MSCs) into 3D spheroids enhances their antiinflammatory properties. Proc Natl Acad Sci USA 31(107):13724-13729

180. Ylostalo JH, Bartosh TJ, Coble K, Prockop DJ (2012) Human mesenchymal stem/stromal cells cultured as spheroids are selfactivated to produce prostaglandin E2 that directs stimulated macrophages into an anti-inflammatory phenotype. Stem Cells (Dayton Ohio) 10(30):2283-2296

181. Ho SS, Murphy KC, Binder BY, Vissers CB, Leach JK (2016) Increased survival and function of mesenchymal stem cell spheroids entrapped in instructive alginate hydrogels. Stem Cells Transl Med 6(5):773-781

182. Cesarz Z, Tamama K (2016) Spheroid culture of mesenchymal stem cells. Stem Cells Int 2016:9176357

183. Li L, Jin S, Zhang Y (2015) Ischemic preconditioning potentiates the protective effect of mesenchymal stem cells on endotoxininduced acute lung injury in mice through secretion of exosome. Int J Clin Exp Med 3(8):3825-3832
184. Seo Y, Shin TH, Kim HS (2019) Current strategies to enhance adipose stem cell function: an update. Int J Mol Sci 20(15):3827

185. Cosgrove BD, Mui KL, Driscoll TP, Caliari SR, Mehta KD, Assoian RK, Burdick JA, Mauck RL (2016) $N$-cadherin adhesive interactions modulate matrix mechanosensing and fate commitment of mesenchymal stem cells. Nat Mater 12(15):1297-1306

186. Fu J, Wang YK, Yang MT, Desai RA, Yu X, Liu Z, Chen CS (2010) Mechanical regulation of cell function with geometrically modulated elastomeric substrates. Nat Methods 9(7):733-736

187. Guvendiren M, Burdick JA (2012) Stiffening hydrogels to probe short- and long-term cellular responses to dynamic mechanics. Nat Commun 3:792

188. Khetan S, Guvendiren M, Legant WR, Cohen DM, Chen CS, Burdick JA (2013) Degradation-mediated cellular traction directs stem cell fate in covalently crosslinked three-dimensional hydrogels. Nat Mater 5(12):458-465

189. Campbell JJ, Bader DL, Lee DA (2008) Mechanical loading modulates intracellular calcium signaling in human mesenchymal stem cells. J Appl Biomater Biomech JABB 1(6):9-15

190. Kasper G, Dankert N, Tuischer J, Hoeft M, Gaber T, Glaeser JD, Zander D, Tschirschmann M, Thompson M, Matziolis G, Duda GN (2007) Mesenchymal stem cells regulate angiogenesis according to their mechanical environment. Stem Cells (Dayton, Ohio) 4(25):903-910

191. Abdeen AA, Weiss JB, Lee J, Kilian KA (2014) Matrix composition and mechanics direct proangiogenic signaling from mesenchymal stem cells. Tissue Eng Part A 19-20(20):2737-2745

192. Gardner OF, Fahy N, Alini M, Stoddart MJ (2016) Differences in human mesenchymal stem cell secretomes during chondrogenic induction. Eur Cells Mater 31:221-235

193. Krampera M, Cosmi L, Angeli R, Pasini A, Liotta F, Andreini A, Santarlasci V, Mazzinghi B, Pizzolo G, Vinante F, Romagnani P, Maggi E, Romagnani S, Annunziato F (2006) Role for interferon-gamma in the immunomodulatory activity of human bone marrow mesenchymal stem cells. Stem Cells (Dayton, Ohio) 2(24):386-398

194. Ryan JM, Barry F, Murphy JM, Mahon BP (2007) Interferongamma does not break, but promotes the immunosuppressive capacity of adult human mesenchymal stem cells. Clin Exp Immunol 2(149):353-363

195. Krampera M (2011) Mesenchymal stromal cell 'licensing': a multistep process. Leukemia 9(25):1408-1414

196. Croitoru-Lamoury J, Lamoury FM, Caristo M, Suzuki K, Walker D, Takikawa O, Taylor R, Brew BJ (2011) Interferon-gamma regulates the proliferation and differentiation of mesenchymal stem cells via activation of indoleamine 2,3 dioxygenase (IDO). PLoS One 2(6):e14698

197. Noone C, Kihm A, English K, O’Dea S, Mahon BP (2013) IFNgamma stimulated human umbilical-tissue-derived cells potently suppress NK activation and resist NK-mediated cytotoxicity in vitro. Stem Cells Dev 22(22):3003-3014

198. Zheng G, Qiu G, Ge M, He J, Huang L, Chen P, Wang W, Xu Q, Hu Y, Shu Q, Xu J (2017) Human adipose-derived mesenchymal stem cells alleviate obliterative bronchiolitis in a murine model via IDO. Respir Res 1(18):119

199. Kronsteiner B, Wolbank S, Peterbauer A, Hackl C, Redl H, van Griensven M, Gabriel C (2011) Human mesenchymal stem cells from adipose tissue and amnion influence T-cells depending on stimulation method and presence of other immune cells. Stem Cells Dev 12(20):2115-2126

200. Prasanna SJ, Gopalakrishnan D, Shankar SR, Vasandan AB (2010) Pro-inflammatory cytokines, IFNgamma and TNFalpha, influence immune properties of human bone marrow and Wharton jelly mesenchymal stem cells differentially. PLoS One 2(5):e9016 
201. Rodriguez TM, Saldias A, Irigo M, Zamora JV, Perone MJ, Dewey RA (2015) Effect of TGF-betal stimulation on the secretome of human adipose-derived mesenchymal stromal cells. Stem Cells Transl Med 8(4):894-898

202. Lu Z, Wang G, Dunstan CR, Chen Y, Lu WY, Davies B, Zreiqat H (2013) Activation and promotion of adipose stem cells by tumour necrosis factor-alpha preconditioning for bone regeneration. J Cell Physiol 8(228): 1737-1744

203. Kwon YW, Heo SC, Jeong GO, Yoon JW, Mo WM, Lee MJ, Jang IH, Kwon SM, Lee JS, Kim JH (2013) Tumor necrosis factoralpha-activated mesenchymal stem cells promote endothelial progenitor cell homing and angiogenesis. Biochem Biophys Acta 12(1832):2136-2144

204. Li C, Li G, Liu M, Zhou T, Zhou H (2016) Paracrine effect of inflammatory cytokine-activated bone marrow mesenchymal stem cells and its role in osteoblast function. J Biosci Bioeng 2(121):213-219

205. Han X, Yang Q, Lin L, Xu C, Zheng C, Chen X, Han Y, Li M, Cao W, Cao K, Chen Q, Xu G, Zhang Y, Zhang J, Schneider RJ, Qian Y, Wang Y, Brewer G, Shi Y (2014) Interleukin-17 enhances immunosuppression by mesenchymal stem cells. Cell Death Differ 11(21):1758-1768

206. Crop MJ, Baan CC, Korevaar SS, Ijzermans JN, Pescatori M, Stubbs AP, van Ijcken WF, Dahlke MH, Eggenhofer E, Weimar W, Hoogduijn MJ (2010) Inflammatory conditions affect gene expression and function of human adipose tissue-derived mesenchymal stem cells. Clin Exp Immunol 3(162):474-486

207. Hwa Cho H, Bae YC, Jung JS (2006) Role of toll-like receptors on human adipose-derived stromal cells. Stem Cells (Dayton, Ohio) 12(24):2744-2752

208. Liotta F, Angeli R, Cosmi L, Fili L, Manuelli C, Frosali F, Mazzinghi B, Maggi L, Pasini A, Lisi V, Santarlasci V, Consoloni L, Angelotti ML, Romagnani P, Parronchi P, Krampera M, Maggi E, Romagnani S, Annunziato F (2008) Toll-like receptors 3 and 4 are expressed by human bone marrow-derived mesenchymal stem cells and can inhibit their T-cell modulatory activity by impairing Notch signaling. Stem Cells (Dayton, Ohio) 1(26):279-289

209. Frith JE, Jaramillo-Ferrada P, Mills RJ, Cameron AR, Titmarsh DM, Wolvetang EJ, Cooper-White JJ (2012) Development of defined culture conditions for expansion of human mesenchymal stromal cells for clinical applications. In: Hayat MA (ed) Stem cells and cancer stem cells, volume 8: therapeutic applications in disease and injury. Springer, Dordrecht, pp 13-26. https://doi. org/10.1007/978-94-007-4798-2

210. Swamynathan $P$, Venugopal $P$, Kannan S, Thej C, Kolkundar U, Bhagwat S, Ta M, Majumdar AS, Balasubramanian S (2014) Are serum-free and xeno-free culture conditions ideal for large scale clinical grade expansion of Wharton's jelly derived mesenchymal stem cells? A comparative study. Stem Cell Res Ther 4(5):88

211. Kaushik G, Ponnusamy MP, Batra SK (2018) Concise review: current status of three-dimensional organoids as preclinical models. Stem Cells (Dayton, Ohio) 9(36):1329-1340

212. Kwok CK, Ueda Y, Kadari A, Günther K, Ergün S, Heron A, Schnitzler AC, Rook M, Edenhofer F (2018) Scalable stirred suspension culture for the generation of billions of human induced pluripotent stem cells using single-use bioreactors. J Tissue Eng Regen Med 2(12):e1076-e1087

213. de Soure AM, Fernandes-Platzgummer A, da Silva CL, Cabral JM (2016) Scalable microcarrier-based manufacturing of mesenchymal stem/stromal cells. J Biotechnol 236:88-109

214. Schonitzer V, Wirtz R, Ulrich V, Berger T, Karl A, Mutschler W, Schieker M, Bocker W (2014) Sox2 is a potent inhibitor of osteogenic and adipogenic differentiation in human mesenchymal stem cells. Cell Reprogram 5(16):355-365

215. Min CK, Kim BG, Park G, Cho B, Oh IH (2007) IL-10-transduced bone marrow mesenchymal stem cells can attenuate the severity of acute graft-versus-host disease after experimental allogeneic stem cell transplantation. Bone Marrow Transpl 10(39):637-645

216. Bian L, Guo ZK, Wang HX, Wang JS, Wang H, Li QF, Yang YF, Xiao FJ, Wu CT, Wang LS (2009) In vitro and in vivo immunosuppressive characteristics of hepatocyte growth factor-modified murine mesenchymal stem cells. In Vivo (Athens, Greece) $1(23): 21-27$

217. Kim DS, Jang IK, Lee MW, Ko YJ, Lee DH, Lee JW, Sung KW, Koo HH, Yoo KH (2018) Enhanced immunosuppressive properties of human mesenchymal stem cells primed by interferongamma. EBioMedicine 28:261-273

218. Qi H, Chen G, Huang Y, Si Z, Li J (2015) Foxp3-modified bone marrow mesenchymal stem cells promotes liver allograft tolerance through the generation of regulatory T cells in rats. J Transl Med 13:274

219. Li W, Ma N, Ong LL, Nesselmann C, Klopsch C, Ladilov Y, Furlani D, Piechaczek C, Moebius JM, Lutzow K, Lendlein A, Stamm C, Li RK, Steinhoff G (2007) Bcl-2 engineered MSCs inhibited apoptosis and improved heart function. Stem Cells (Dayton Ohio) 8(25):2118-2127

220. Fierro FA, Kalomoiris S, Sondergaard CS, Nolta JA (2011) Effects on proliferation and differentiation of multipotent bone marrow stromal cells engineered to express growth factors for combined cell and gene therapy. Stem Cells (Dayton, Ohio) 11(29):1727-1737

221. Eun LY, Song BW, Cha MJ, Song H, Kim IK, Choi E, Chang W, Lim S, Choi EJ, Ham O, Lee SY, Byun KH, Jang Y, Hwang KC (2010) Overexpression of phosphoinositide-3-kinase class II alpha enhances mesenchymal stem cell survival in infarcted myocardium. Biochem Biophys Res Commun 2(402):272-279

222. Fan L, Lin C, Zhuo S, Chen L, Liu N, Luo Y, Fang J, Huang Z, Lin Y, Chen J (2009) Transplantation with survivin-engineered mesenchymal stem cells results in better prognosis in a rat model of myocardial infarction. Eur J Heart Fail 11(11):1023-1030

223. Tang J, Wang J, Yang J, Kong X, Zheng F, Guo L, Zhang L, Huang Y (2009) Mesenchymal stem cells over-expressing SDF-1 promote angiogenesis and improve heart function in experimental myocardial infarction in rats. Eur J Cardio-thorac Surg 4(36):644-650

224. Wiehe JM, Kaya Z, Homann JM, Wohrle J, Vogt K, Nguyen T, Rottbauer W, Torzewski J, Fekete N, Rojewski M, Schrezenmeier H, Moepps B, Zimmermann O (2013) GMP-adapted overexpression of CXCR4 in human mesenchymal stem cells for cardiac repair. Int J Cardiol 5(167):2073-2081

225. Song YS, Lee HJ, Doo SH, Lee SJ, Lim I, Chang KT, Kim SU (2012) Mesenchymal stem cells overexpressing hepatocyte growth factor (HGF) inhibit collagen deposit and improve bladder function in rat model of bladder outlet obstruction. Cell Transplant 8(21):1641-1650

226. Kucic T, Copland IB, Cuerquis J, Coutu DL, Chalifour LE, Gagnon RF, Galipeau J (2008) Mesenchymal stromal cells genetically engineered to overexpress IGF-I enhance cell-based gene therapy of renal failure-induced anemia. Am J Physiol Renal Physiol 2(295):F488-F496

227. Weissmiller AM, Wu C (2012) Current advances in using neurotrophic factors to treat neurodegenerative disorders. Transl Neurodegener 1(1): 14

228. Balaratnasingam S, Janca A (2012) Brain derived neurotrophic factor: a novel neurotrophin involved in psychiatric and neurological disorders. Pharmacol Ther 1(134):116-124

229. Benussi L, Binetti G, Ghidoni R (2017) Loss of neuroprotective factors in neurodegenerative dementias: the end or the starting point? Front Neurosci 11:672

230. Bhardwaj R, Deshmukh R (2018) Neurotrophic factors and Parkinson's disease. Clin Investig 7(4):53-62 
231. Bezdjian A, Kraaijenga VJ, Ramekers D, Versnel H, Thomeer HG, Klis SF, Grolman W (2016) Towards clinical application of neurotrophic factors to the auditory nerve; assessment of safety and efficacy by a systematic review of neurotrophic treatments in humans. Int J Mol Sci 17(12):1981

232. Scheper V, Schwieger J, Hamm A, Lenarz T, Hoffmann A (2019) BDNF-overexpressing human mesenchymal stem cells mediate increased neuronal protection in vitro. J Neurosci Res 11(97):1414-1429

233. Nakamizo A, Marini F, Amano T, Khan A, Studeny M, Gumin J, Chen J, Hentschel S, Vecil G, Dembinski J, Andreeff M, Lang FF (2005) Human bone marrow-derived mesenchymal stem cells in the treatment of gliomas. Cancer Res 8(65):3307-3318

234. Ren C, Kumar S, Chanda D, Kallman L, Chen J, Mountz JD, Ponnazhagan S (2008) Cancer gene therapy using mesenchymal stem cells expressing interferon-beta in a mouse prostate cancer lung metastasis model. Gene Ther 21(15):1446-1453

235. Li X, Lu Y, Huang W, Xu H, Chen X, Geng Q, Fan H, Tan Y, Xue G, Jiang X (2006) In vitro effect of adenovirus-mediated human Gamma Interferon gene transfer into human mesenchymal stem cells for chronic myelogenous leukemia. Hematol Oncol 3(24):151-158

236. Xin H, Kikuchi T, Andarini S, Ohkouchi S, Suzuki T, Nukiwa T, Huqun, Hagiwara K, Honjo T, Saijo Y (2005) Antitumor immune response by CX3CL1 fractalkine gene transfer depends on both NK and T cells. Eur J Immunol 5(35):1371-1380

237. Eliopoulos N, Francois M, Boivin M-N, Martineau D, Galipeau J (2008) Neo-organoid of marrow mesenchymal stromal cells secreting Interleukin-12 for breast cancer therapy. Cancer Res 12(68): 4810

238. Boulaiz H, Marchal JA, Prados J, Melguizo C, Aranega A (2005) Non-viral and viral vectors for gene therapy. Cell Mol Biol (Noisy-le-Grand Fr) 1(51):3-22

239. Golchin A, Shams F, Karami F (2020) Advancing mesenchymal stem cell therapy with CRISPR/Cas9 for clinical trial studies. In: Turksen K (ed) Cell biology and translational medicine, vol 8. stem cells in regenerative medicine. Springer International Publishing, Cham, pp 89-100

240. Filho DM, de Carvalho Ribeiro P, Oliveira LF, dos Santos ALRT, Parreira RC, Pinto MCX, Resende RR (2019) Enhancing the therapeutic potential of mesenchymal stem cells with the CRISPR-Cas system. Stem Cell Rev Rep 4(15):463-473

241. Deryabin P, Griukova A, Shatrova A, Petukhov A, Nikolsky N, Borodkina A (2019) Optimization of lentiviral transduction parameters and its application for CRISPR-based secretome modification of human endometrial mesenchymal stem cells. Cell Cycle 6-7(18):742-758

242. Meng X, Zheng M, Yu M, Bai W, Zuo L, Bu X, Liu Y, Xia L, Hu J, Liu L, Li J (2019) Transplantation of CRISPRa system engineered IL10-overexpressing bone marrow-derived mesenchymal stem cells for the treatment of myocardial infarction in diabetic mice. J Biol Eng 13:49

243. Yeo RW, Lai RC, Zhang B, Tan SS, Yin Y, Teh BJ, Lim SK (2013) Mesenchymal stem cell: an efficient mass producer of exosomes for drug delivery. Adv Drug Deliv Rev 3(65):336-341

244. Lou G, Chen Z, Zheng M, Liu Y (2017) Mesenchymal stem cellderived exosomes as a new therapeutic strategy for liver diseases. Exp Mol Med 6(49):e346
245. Kooijmans SA, Vader P, van Dommelen SM, van Solinge WW, Schiffelers RM (2012) Exosome mimetics: a novel class of drug delivery systems. Int J Nanomed 7:1525-1541

246. Zhuang X, Xiang X, Grizzle W, Sun D, Zhang S, Axtell RC, Ju S, Mu J, Zhang L, Steinman L, Miller D, Zhang HG (2011) Treatment of brain inflammatory diseases by delivering exosome encapsulated anti-inflammatory drugs from the nasal region to the brain. Mol Ther J Am Soc Gene Ther 10(19):1769-1779

247. O’Brien KP, Khan S, Gilligan KE, Zafar H, Lalor P, Glynn C, O'Flatharta C, Ingoldsby H, Dockery P, De Bhulbh A, Schweber JR, St John K, Leahy M, Murphy JM, Gallagher WM, O'Brien T, Kerin MJ, Dwyer RM (2018) Employing mesenchymal stem cells to support tumor-targeted delivery of extracellular vesicle (EV)-encapsulated microRNA-379. ACS Appl Mater Interfaces 16(37):2137-2149

248. Zhou A, Feng S, Li Y, Liu T, Ye Z, Zhang T, He W, Jin H, Liu C, Yang Z, Ren J (2018) Methotrexate-loaded extracellular vesicles functionalized with therapeutic and targeted peptides for the treatment of glioblastoma multiforme. PLoS One 15(10):12341-12350

249. Ban JJ, Lee M, Im W, Kim M (2015) Low pH increases the yield of exosome isolation. Biochem Biophys Res Commun 1(461):76-79

250. Chen L, Charrier A, Zhou Y, Chen R, Yu B, Agarwal K, Tsukamoto H, Lee LJ, Paulaitis ME, Brigstock DR (2014) Epigenetic regulation of connective tissue growth factor by microRNA-214 delivery in exosomes from mouse or human hepatic stellate cells. Hepatology (Baltimore Md) 3(59):1118-1129

251. Batrakova EV, Kim MS (2015) Using exosomes, naturallyequipped nanocarriers, for drug delivery. J Control Release 219:396-405

252. Chen TS, Arslan F, Yin Y, Tan SS, Lai RC, Choo AB, Padmanabhan J, Lee CN, de Kleijn DP, Lim SK (2011) Enabling a robust scalable manufacturing process for therapeutic exosomes through oncogenic immortalization of human ESC-derived MSCs. J Transl Med 9:47

253. Feng Y, Huang W, Wani M, Yu X, Ashraf M (2014) Ischemic preconditioning potentiates the protective effect of stem cells through secretion of exosomes by targeting Mecp2 via miR-22. PLoS One 2(9):e88685

254. Melzer C, Rehn V, Yang Y, Bahre H, von der Ohe J, Hass R (2019) Taxol-loaded MSC-derived exosomes provide a therapeutic vehicle to target metastatic breast cancer and other carcinoma cells. Cancers 11(6):798

255. Ankrum J (2020) Cell therapies can bring insult to injury. Sci Transl Med 532(12):eabb0792

256. Zhang H, Li C, Chen H, Wei C, Dai F, Wu H, Dui W, Deng WM, Jiao R (2015) SCF(Slmb) E3 ligase-mediated degradation of Expanded is inhibited by the Hippo pathway in Drosophila. Cell Res 1748-7838 (Electron) 25:93-109

Publisher's Note Springer Nature remains neutral with regard to jurisdictional claims in published maps and institutional affiliations. 